\title{
Sources of Pollutants in the Northern/Northeast Area of Guanabara Bay (SE, BRAZIL) Since THE LATE NineteENTH CENTURY Using LeAd Isotopes And Metal Concentrations
}

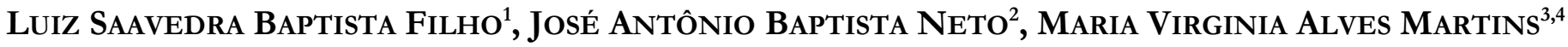 AND MAURo CESAR GERALDES ${ }^{3 *}$}

1 Universidade do Estado do Rio de Janeiro, Departamento de Geografia Física, Instituto de Geografia, Rua São Francisco Xavier, 524, Maracanã, Rio de Janeiro, RJ, Brazil

2 Universidade Federal Fluminense, Niteroi, Rio de Janeiro, RJ, Brazil

3 Universidade do Estado do Rio de Janeiro, Faculdade de Geologia, Rua São Francisco Xavier, 524, Maracanã, Rio de Janeiro, RJ, Brazil

4 Universidade de Aveiro, Departamento de Geociências, GeoBioTec, Aveiro, Portugal

*CORRESPONDING AUTHOR, geraldes@uerj.br

Received on 06 August 2019

Received in revised form on 26 September 2019

Accepted on 28 September 2019

\section{Editor: Noureddine Zaaboub, Institut National des Sciences et Technologies de la} Mer, Tunis, Tunisia

\section{Abstract}

The coastal areas, the most populated regions in the world, are those which have undergone the greatest human influence. In Brazilian southeastern coast, the region around Guanabara Bay (GB) is one of the most densely populated, with large cities, such as Rio de Janeiro and Niteroi, and is highly industrialized. Due to anthropic activities tones of effluents, waste and sewage is daily released in GB. Despite, several works have been performed aiming to study the current and past human influence in GB, the sources of pollutants that have impacted this bay since the late nineteenth century. This work is a new contribution aiming to identify the main sources of pollution in the northern/northeast region of GB using stable isotopes of lead $(\mathrm{Pb})$ and metal concentrations during the last decades. It analyses results obtained along the core T3 collected in the northeast region of Guanabara Bay, near the Guapimirim Environmental Protected Area (known as Apa de Guapimirim), a mangrove fringe. Twenty-two sediment samples collected along this core were submitted to grain size, total organic carbon content (TOC), elemental concentrations ( $\mathrm{Ag}, \mathrm{Ca}, \mathrm{Cu}, \mathrm{P}, \mathrm{Pb}, \mathrm{S}$ and $\mathrm{Zn}$ ) and stable isotopes of lead $(\mathrm{Pb})$ analyses. The sediment accumulation

\section{Introduction}

Stable isotopes of lead $\left({ }^{204} \mathrm{~Pb},{ }^{206} \mathrm{~Pb},{ }^{207} \mathrm{~Pb},{ }^{208} \mathrm{~Pb}\right)$ are generated from decay of $238 \mathrm{U}\left({ }^{206} \mathrm{~Pb}\right),{ }^{235} \mathrm{U}\left({ }^{207} \mathrm{~Pb}\right)$ and ${ }^{232} \mathrm{Th}$ $\left({ }^{208} \mathrm{~Pb}\right)$ isotopes (Faure, 1986; Turekian and Holland, 2013).
Citation:

Baptista Filho, L.S., Baptista Neto, J.A., Alves Martins, M.V., Geraldes, M.C., 2019. Sources of pollutants in the Northern/Northeast area of Guanabara Bay (SE, Brazil) since the late nineteenth century using lead isotopes and metals concentrations. Journal of Sedimentary Environments, 4 (3): 332-349.

rate was estimated by ${ }^{210} \mathrm{~Pb}$. Results of core T3 were compared with similar data acquired in core $\mathrm{T} 8$, collected in Guanabara Bay, at north of Paquetá island. The comparison of the geochemical results allowed to verify that both cores recorded the same reality. Previous works have shown that the northern/northeast region of Guanabara Bay is low polluted by metals, however, since the $\approx 1950$ a marked increase in eutrophication and metal contamination and another noticeable pulse after $\approx 1970$, were recorded in both cores studied in this work. The ${ }^{206} \mathrm{~Pb} / 207 \mathrm{~Pb}$ values suggest that the main source of pollutants to northern/northeast region of GB since the second half of the $20^{\text {th }}$ century have been related to deforestation and landfill and embankment engineering works preformed around the GB, in addition to mineral products applied in industrial goods, as well as oil, agricultural and organic loads.

Keywords: Metal Concentrations. $\mathrm{Pb}$ isotopes. Contamination. Pollutant sources. Coastal area. Anthropogenic record.

The ${ }^{204} \mathrm{~Pb}$, originated during the solar system formation, is the only natural radioactive isotope considered stable (Austin, 2005). It is therefore used as a reference for the standardization of other isotopes of this element 
$\left(206 \mathrm{~Pb} / 204 \mathrm{~Pb},{ }^{207} \mathrm{~Pb} / 204 \mathrm{~Pb}\right.$ and $\left.208 \mathrm{~Pb} / 204 \mathrm{~Pb}\right)$ due to its long half-life (>1.4 x $10^{17}$ years; Machado et al., 2004).

According to Oh et al. (2004) and Duzgoren-Aydin and Weiss (2008), the isotopic composition of a lead ore is dependent on the original concentrations of $\mathrm{Pb}, \mathrm{U}$ and $\mathrm{Th}$, and the age of deposition. The industrial materials of this ore carry its isotopic signature. Similarly, lead in several nonmineral materials, such as coal and soil, also has a particular isotopic composition due to the presence of $\mathrm{U}$ and $\mathrm{Th}$ (Bacon et al., 2006; Tserenpil et al., 2016). Thus, lead released into the atmosphere by combustion, melting and other processes keeps the original isotopic composition (Doucet and Carignan, 2001; Clarke et al., 2004; Simoneit et al., 2004). Since, the normal chemical and physical processes do not affect the original isotopic composition, it is possible to estimate $\mathrm{Pb}$ sources in aerosols through isotopic composition analysis (Komárek et al., 2008; Widory et al., 2010).

Environmental studies conducted since the 1960s demonstrated the applicability of lead isotopic ratios in pollution assessment, since $\mathrm{Pb}$ scattered in the environment, from natural or anthropic processes, has the same isotopic characteristics of the source material (Patterson, 1965; Bindler, 2011; Ignacio et al., 2019; Potratz et al., 2019). Thus, the isotopic composition of $\mathrm{Pb}$ in a contaminated environment will be identical to that of the contaminating source (isotopic signature), allowing its identification when the isotopic compositions of different materials that compose a certain area of study are well known (e.g., Chow and Patterson, 1962; Patterson and Hirao, 1974; Shirahata et al., 1980). As the natural environment (bay or river) is submitted to the influence of several natural and anthropogenic sources, it is necessary to discriminate isotopically all possible and most important sources of lead, so that calculations of mass balance allow to characterize the contribution of each one and to separate the natural lead from the anthropogenic one (e.g., Bacon et al., 1995, 1996, 2006; Farmer et al., 1996, 2002; Shotyk et al., 1998; Weiss et al., 1999; Kaste et al., 2003; Watmough et al., 2004; Le Roux et al., 2005; Steinnes et al., 2005; Graham et al., 2006; Cloy et al., 2008).

Recent studies of lead isotopes have shown that it is possible to trace their origin in several environments, such as water and sediments of rivers, lakes, oceans, aerosols, lichens and mosses, rainwater, and fuels such as alcohol, gasoline and diesel (Babinski et al., 2005; Díaz Morales, 2019a; Ignacio et al., 2019; Potratz et al., 2019). Its most common applications to identify sources of pollution have been focused on surface water, groundwater, atmosphere and soil surface layers (e.g. Gulson et al. 1992; Rosman et al. 1994; Kober et al. 1999; Miller et al. 2002, 2005; Bollhöfer et al. 2005; Leybourne et al., 2009; Souza et al., 2017).

Sedimentary records collected in calm environments of bays and lakes naturally concentrate fine sediments and organic matter (Borges and Nittrouer, 2016; Delavy et al.,
2016; Laut et al., 2016, 2019; Dias et al., 2017; Alves Martins et al., 2018; Pregnolato et al., 2018). These materials have great affinity to heavy metals (Alves Martins 2015; Martins et al., 2015, 2017; Suzuki et al, 2016; Zaaboub et al., 2016; Díaz Morales et al., 2019b) and can provide temporal information regarding the beginning of anthropic influence in the environment (Vilela et al., 2014; Bueno et al., 2019), which is one of the objectives of this research.

Ferrand et al. (1999), analyzing stable isotopes of lead in 24 cores $(0-50 \mathrm{~cm})$ of several transects in the Gulf of Lion (France), observed that lead concentrations (23-85 ppm) and isotopic signatures ${ }^{206} \mathrm{~Pb} /{ }^{207} \mathrm{~Pb}(1.174-1.188)$ in the surface sediments, clearly evidenced the impact of polluting lead, which contributed for $22-80 \%$ of the lead accumulated in the first centimeter of the sediments in the studied sites.

Desenfant et al. (2006) reconstructed the transport of pollutant $\mathrm{Pb}$ and its entry into the Caribbean basin in relation to past weather changes and industrial activities, based on geochemical data obtained from massive corals collected in 1998 in Mona Island. A striking relationship was found between the isotopic impressions of lead and the North Atlantic oscillation index for two specific periods (19141929 and 1965-1997), characterized by distinct isotopic signatures of the main pollutant emitter of $\mathrm{Pb}$ to the North Atlantic troposphere, North America and Western Europe (Nriagu, 1990). Thus, variations of radiogenic isotopes can provide independent and useful information in studies of sedimentary and environmental geology, being useful to: i) investigate the sources and transport of dissolved and particulate materials in the hydrological, sedimentary and biogeochemical cycles in ecosystems; ii) to reconstruct temporal changes in the ocean water chemistry and; iii) to point out changes in studies of stratigraphic correlation.

Several studies investigated long-term trends both in water (e.g., Mayr, 1998; Paranhos et al., 1995; Contador and Paranhos, 1996) and in sediment records (e.g. Barth et al., 2004; Pereira et al., 2007; Borges e al., 2009; Vilela et al., 2014; Baptista Neto et al., 2017) of negative impacts in Guanabara Bay. However, the main determinant sources of pollutants for the north/northeastern area of GB, which is considered less polluted by metals (Baptista Neto et al., 2006; Potratz et al., 2019) during the last decades are not yet known.

The main aim of this work is to find geological records of the anthropic influence in Guanabara Bay (SE, Brazil), including increasing of organic matter and contamination by metals, in two cores collected in the innermost northern/northeast region of this coastal system. It also intends to identify sources of pollutants using lead isotopes.

\subsection{Study Area}

Guanabara Bay (southeastern Brazil) is located between the latitudes $22^{\circ} 24^{\prime}$ and $22^{\circ} 57$ 'S and longitudes $42^{\circ} 33^{\prime}$ and $43^{\circ} 19^{\prime} \mathrm{W}$. It practically encompasses the entire metropolitan 
region of Rio de Janeiro and, despite being of incontestable historical, economic, cultural, scientific, social and environmental importance, it is one of the most degraded coastal environments in the country (Baptista Neto et al., 2013). It is a complex ecosystem which includes for instance forests, mangroves, marshes, wetlands, lagoons, dunes, beaches, rivers, estuaries, coves, islands, slabs, pinnacles, rocky outcrops and cliffs (Amador, 1997).

Guanabara Bay has approximately $381 \mathrm{~km}^{2}$ of surface or water mirror, carrying a volume of $\approx 3$ billion cubic meters of water (Amador, 1997). It measures $28 \mathrm{~km}$ long in a northsouth direction and a maximum east-west width of $27 \mathrm{~km}$. The depth reaches a maximum of 50 meters near the entrance and an average of 7.6 meters. The main channel, in a north-south direction, measures approximately $20 \mathrm{~km}$ in length, with an average depth of 15 to 20 meters and a width of $3 \mathrm{~km}$ (SEMADS, 2001). Its internal area is shallower with depths $<3.0 \mathrm{~m}$ near the margins. GB has a narrow entrance of about $1.6 \mathrm{~km}$ wide (Kjerfve et al., 1997). The lower stretches of many rivers have been modified since the late nineteenth and early twentieth centuries through drainage works performed by federal, state and municipal public agencies.

Situated in the middle of an intertropical area and squeezed between sea and mountain, the climate of the region is generally hot and humid. The annual average temperature is $\approx 24^{\circ} \mathrm{C}$, reaching maximum values $>40{ }^{\circ} \mathrm{C}$. The average annual total precipitation ranges between 1,000 and $1,500 \mathrm{~mm}$. In winter there is a tendency for a dry season, while summer is characterized by torrential rain.

The factors that determine the circulation pattern in Guanabara Bay are: tidal range, coastal morphology, bathymetry (Catanzaro et al., 2004), wind regime and freshwater input from river basins. Circulation governed by tidal ebb and flow is predominant, with a semi-diurnal regime (INEA). Because the bottom topography, it has in its central part a natural deeper channel; the flow is all induced to this area, generating more intense currents (INEA). In the innermost part of the Bay, where the depths are lower, there is a progressive loss of currents velocity, causing a mixture of oceanic and inland waters.

Around the Bay live about 10 million inhabitants distributed among 16 municipalities: Duque de Caxias, Mesquita, São João de Meriti, Belford Roxo, Nilópolis, São Gonçalo, Magé, Guapimirim, Itaboraí, Tanguá and partially Rio de Janeiro, Niterói, Nova Iguaçu, Cachoeiras de Macacu, Rio Bonito and Petrópolis. The 4,081 km² river basin houses 25 basins and sub-basins, considered the most representative, whose main waterways carry most of the pollution generated on the mainland to the Bay.

The anthropic impact in this bay reflect different stages of industrial expansion, with the larger development of the urban-industrial occupation in the last decades which has been triggering a progressive and marked environmental degradation (Amador, 1997; Barth et al., 2004; Pereira et al.,
2007; Vilela et al., 2014; Baptista Neto et al., 2017). Its landscape of tropical paradise was altered, initially with the exploration of Brazil wood, then with its occupation and defense, that would lead to the creation of the City of São Sebastião do Rio de Janeiro by the Portuguese colonizers, ongoing with the economic cycles of sugarcane, mining, coffee and, lastly, industrialization (Amador, 1997).

Nowadays, Guanabara Bay holds the country's second industrial park, an exceptionally large refinery (REDUC), two commercial ports (Rio de Janeiro and Niterói), 16 maritime oil terminals and 12 shipyards, all of which are major sources of pollution. Guanabara Bay produces 18.6 $\mathrm{m}^{3} / \mathrm{s}$ of raw sewage from $\approx 9$ million inhabitants, and $470 \mathrm{t}$ of organic load, $64 \mathrm{t}$ of industrial waste, $0.3 \mathrm{t}$ of heavy metals, $7 \mathrm{t}$ of oil and 6t of garbage are dumped daily. The main sources of pollution are the 6,000 industries. In Guanabara Bay, approximately 13,000 t/day of garbage is generated, and $4,000 \mathrm{t} /$ day is not collected, being leaked on vacant lots, rivers and canals.

\section{Materials and methods}

\subsection{Cores location}

This study analyses grain size and geochemical results obtained in cores T3 (Latitude 22.41'10" S, Longitude 43047.9" W, $1 \mathrm{~m}$ deep; $197 \mathrm{~cm}$ long) and T8 (Latitude $22^{\circ} 44^{\prime} 28^{\prime \prime}$ S, Longitude 4306'45" W, 4 m deep; 242 cm long) collected in the north-northeast part of Guanabara Bay (SE, Brazil; Fig. 1). These cores were collected in 2001 by percussion drilling using PVC pipes ( $7 \mathrm{~cm}$ in diameter), by a team from the Marine Geology Laboratory of Universidade Federal Fluminense (LAGEMAR/UFF, Rio de Janeiro State, Brazil).

Core T8 also was previously studied by Vilela et al. (2014) for TOC and foraminifera content and Baptista Neto et al. (2017) comparing foraminifera, pollen, TOC and metals, for paleoenvironmental reconstruction for the last 5000 years. This work mostly compares results of the upper $197 \mathrm{~cm}$ of cores T3 and T8 and analyses stable isotopes of lead and geochemical data (TOC and elemental concentrations) aiming to identify the main sources of pollution in the $\mathrm{N} / \mathrm{NE}$ area of GB, since the late nineteenth century.

Core T3 was retrieved near the Guapimirim Environmental Protected Area (known as Apa de Guapimirim), a mangrove fringe where several rivers flow, and close the Iriri river mouth, a meandering river with low competence to transport sediment (Fig. 1). Core T8 was recovered at north of the Paquetá island (Fig. 1), in an area protected from strong hydrodynamics caused by cold fronts that sometimes reach Guanabara Bay (GB) from south to north, acting very effectively on their water and sediment dynamics. For this work, along the cores T3 and T8 were collected 22 and 20 samples, respectively, of $2 \mathrm{~cm}$ thicknes 


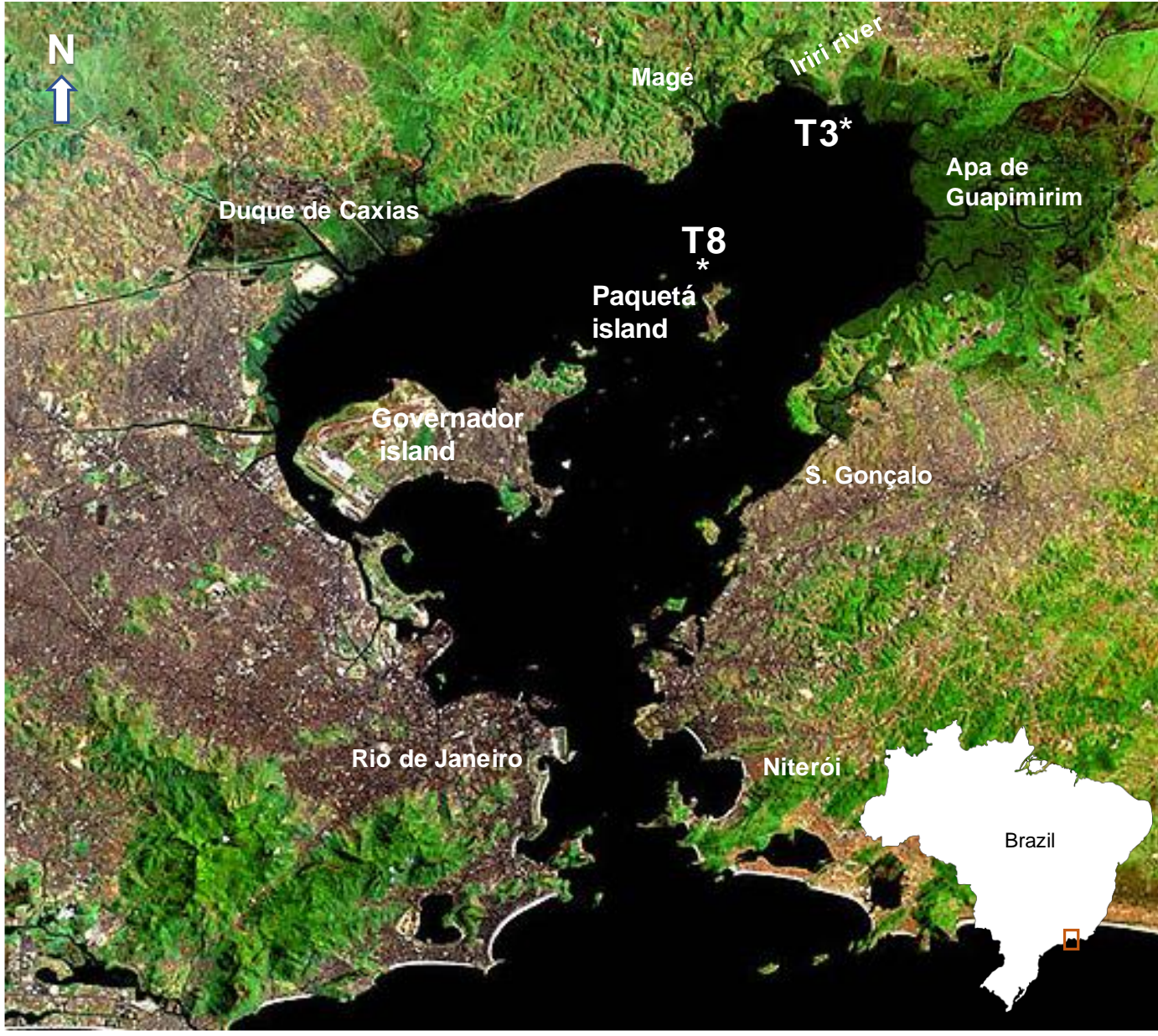

Fig. 1. Location of the studied cores T3 and T8, in Guanabara Bay (SE, Brazil). Adapted from a satellite image of NOOA.

\subsection{Sediment grain size and geochemical analysis}

Particle size analysis was carried out using a Malvern Mastersizer Microplus MAF 5001 of the Laboratory of Particulate Systems, of PEQ/COPPE/UFRJ, which determines the distribution of particle sizes in the diameter range $0.5-550 \mu \mathrm{m}$. This analysis provides the relative abundance of particles for size classes and statistical sedimentological parameters such as the sediment mean grain size.

Total organic carbon content was determined in each sample using the CS infrared analyzer (model Eltra Metalyt 1000CS) from the Leibniz Institute for Baltic Sea Research Warnemünde, Germany.

Elemental concentrations and lead isotopes were analyzed in the section $1-197 \mathrm{~cm}$, of cores T3 and T8. Elemental concentrations (Ag, Ca, Cu, P, Pb, $\mathrm{S}$ and $\mathrm{Zn}$ ) were determined in fine fraction (sediment fraction $<0.062 \mathrm{~mm}$ ) according to the methodology described by Baptista Neto et al. (2017). Samples were digested with aqua regia under pressure using a Perkin Elmer microwave digestion system (USEPA 3051a). Elemental analysis was carried out using a Perkin Elmer Analyst 200 atomic absorption spectrophotometer. Sample blanks and a reference sediment WQB-1 from the National Laboratory for Environmental Testing, Burlington, Canada, were used at regular intervals to monitor quality control.

A concentration factor was estimated for the analyzed elements by dividing the concentration of each element $\left(\mathrm{C}_{\text {metal }}\right)$ in the sediments of the studied cores by the respective baseline concentration $\left(\mathrm{C}_{\text {basseline }}\right)$, proposed by Pinto et al. (2019):

$$
\text { CFmetal }=\frac{C_{\text {metal }}}{C_{\text {baseline }}}
$$

Lead isotopes were analyzed in 42 layers of core T3 (22 samples) and core T8 (20 samples). About 2 grams of the sediment fraction $<0.062 \mathrm{~mm}$ was sent to the Activation Laboratories LTD, in Ontario, Canada. The analyzes, with the error calculated in duplicate and using the reference NIST981 for calibration, followed the following steps: (i) Total digestion of the sediment sample using nitric, hydrochloric, hydrofluoridic and perchloric acids; (ii)

Determination of concentrations using the Plasma Induction Mass Spectrometry (ICP-MS) for the elemental concentration analysis and; High-resolution Plasma 
Induction Mass Spectrophotometer (HR ICP-MS) for lead isotopes, in the samples with lead concentrations $\geq 15 \mathrm{mg} \mathrm{kg}^{-1}$.

\subsection{Age control}

The age control in core T3 was based on ${ }^{210} \mathrm{~Pb}$ data activities, determined by gamma-ray spectrometry, by collecting sediment samples at $\approx 5 \mathrm{~cm}$ intervals down to a depth of $180 \mathrm{~cm}$. Gamma-ray measurements were performed using a semi-planar intrinsic germanium high purity coaxial detector with $40 \%$ efficiency. This was housed in a lead shield and coupled to a multichannel analyzer. Activity was calculated according to Patchineelam and Smoak (1999). The sedimentation rate was calculated by dividing the ${ }^{210} \mathrm{~Pb}$ decay constant by the slope of the loglinear plot of unsupported ${ }^{210} \mathrm{~Pb}$ versus depth (Appleby and Oldfield, 1992).

\subsection{Statistical Analyses}

Elemental concentrations, TOC contents and ${ }^{206} \mathrm{~Pb} /{ }^{207} \mathrm{~Pb}$ values obtained along the cores T3 and T8 were transformed by $\log (\mathrm{x}+1)$ and submitted to Principal Components Analysis (PCA). The PCA was carried out aiming to explain the variance-covariance structure of the studied data and to select the principal components with the largest variance. Pearson correlations between the analyzed variables also were determined. These statistical treatments were performed using a Statsoft software (Statistica 12). Depth plots and bi-plots and linear regression lines and respective $\mathrm{R}^{2}$ were performed with the Microsoft Excel software.

\section{Results}

\subsection{Age model}

According to the results presented in Fig. 2, the sediment accumulation rate of core T3 is $0.67 \mathrm{~cm} \mathrm{yr}^{-1}$, between the top and level of $70 \mathrm{~cm}$. Based on ${ }^{210} \mathrm{~Pb}$ geochronology we can estimate that the section below $150 \mathrm{~cm}$ was deposited before 1900 AD (AD: Ano Domine), between 75-0 cm was deposited after $\approx 1950$ AD; the section between $45-0$ have sediments deposited after $\approx 1970$ AD.

\subsection{Sediment Mean Grain Size and Total Organic Carbon}

Both T3 and T8 cores are essentially fine-grained sequences. Core T3 is composed by a muddy sedimentary sequence, with sediment mean grain size (SMGS) ranging from 5.4-8.3 $\Phi$ (Table 1). Small oscillations of SMGS around the mean value $(7.0 \pm 0.6 \Phi)$ are observed along this core. In core T8, SMGS is more variable ranging from 0.6 to $9.9 \Phi$ (mean 5.4 $2.7 \Phi)$ (Table 1).
RESEARCH PAPER

Total organic carbon (TOC) content (Table 1 and Fig. 3) varied in core T3 between 1.0-5.8 \% (mean 3.2 $\pm 1.6 \%$ ) and in core T8 between 1.4-5.4\% (mean 3.4 $1.2 \%$ ). In both cores, TOC values are lower in the section below $80 \mathrm{~cm}$ and increase progressively to the top until reaching values $>5 \%$ (Fig. 3).

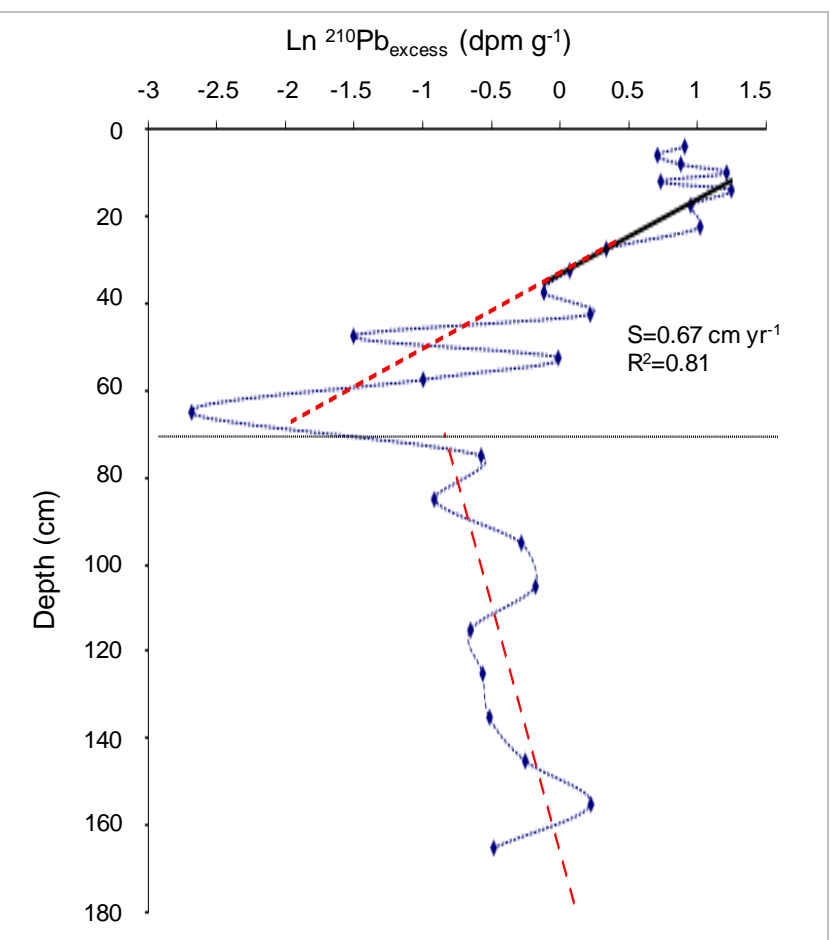

Fig. 2. Estimated sediment accumulation rate for core T3, based on ${ }^{210} \mathrm{~Pb}$. The trend lines for two sections of this core are represented in dash red. The $\mathrm{R}^{2}$ of the upper section trend line and the estimated sediment accumulation rate are presented.

\subsection{The isotopic signature of $\mathrm{Pb}$ in sediments}

Lead isotope data of cores T3 and T8 were included in Table 2 and Appendix 1 . The ${ }^{206} \mathrm{~Pb} /{ }^{207} \mathrm{~Pb}$ ratios oscillated in core T3 between 1.15 and 1.20 (mean 1.18) and in core T8 from 1.14 to 1.20 (mean 1.17). The depth plots of ${ }^{206} \mathrm{~Pb} /{ }^{207} \mathrm{~Pb}$ ratios along the cores $\mathrm{T} 3$ and $\mathrm{T} 8$, presented in Fig. 3, show that these ratios tend to decrease in the upper sections of both cores.

\subsection{Elemental concentrations along the cores $\mathrm{T} 3$ and $\mathrm{T} 8$}

The results of elemental concentrations (Ag, Ca, Cu, P, $\mathrm{Pb}, \mathrm{S}$ and $\mathrm{Zn}$ ) in cores T3 and T8 are presented in Table 3. In core T3 they ranged for: $\mathrm{Ag}$ from $0.29-1.60 \mathrm{mg} \mathrm{kg}^{-1}$ (mean $0.47 \mathrm{mg} \mathrm{kg}^{-1}$ ); Ca from 0.41-2.30\% (mean 1.11\%); Cu from 12-70 mg kg-1 (mean $37 \mathrm{mg} \mathrm{kg}^{-1}$ ); $\mathrm{P}$ from $0.067-0.132 \%$ (mean $0.080 \%$ ); Pb from 16-73 $\mathrm{mg} \mathrm{kg}^{-1}$ (mean $48 \mathrm{mg} \mathrm{kg}^{-1}$ ); $\mathrm{S}$ from $0.75-1.61 \%$ (mean $1.03 \%$ ) and; $\mathrm{Zn}$ from $71-238 \mathrm{mg}$ $\mathrm{kg}^{-1}$ (mean $146 \mathrm{mg} \mathrm{kg}^{-1}$ ). 
In core $\mathrm{T} 8$ the elemental concentrations ranged for: $\mathrm{Ag}$ from $0.29-1.80 \mathrm{mg} \mathrm{kg}^{-1}$ (mean $1.07 \mathrm{mg} \mathrm{kg}-1$ ); Ca from 0.41 $2.49 \%$ (mean $1.16 \%$ ); Cu from 11-84 $\mathrm{mg} \mathrm{kg}^{-1}$ (mean $54 \mathrm{mg}$ $\mathrm{kg}^{-1}$ ); P from $0.0670-0.1510 \%$ (mean $0.1011 \%$ ); Pb from 14$70 \mathrm{mg} \mathrm{kg}^{-1}$ (mean $50 \mathrm{mg} \mathrm{kg}^{-1}$ ); S from 1.00-1.70\% (mean $1.46 \%$ ) and; Zn from 68-248 $\mathrm{mg} \mathrm{kg}^{-1}$ (mean $190 \mathrm{mg} \mathrm{kg}^{-1}$ ).

Tab. 1. Sediment mean grain size $(\varphi)$ and total organic carbon (TOC; \%) along the cores T3 and T8. SD - Standard deviation.

\begin{tabular}{|c|c|c|c|c|}
\hline \multirow{2}{*}{$\begin{array}{l}\text { Depth } \\
\text { (cm) }\end{array}$} & \multicolumn{2}{|c|}{$\begin{array}{c}\text { Sediment Mean } \\
\text { Grain Size }(\Phi)\end{array}$} & \multicolumn{2}{|c|}{$\begin{array}{c}\text { Total Organic } \\
\text { Carbon (TOC; } \% \text { ) }\end{array}$} \\
\hline & $\begin{array}{c}\text { Core } \\
\text { T3 }\end{array}$ & $\begin{array}{c}\text { Core } \\
\text { T8 }\end{array}$ & $\begin{array}{c}\text { Core } \\
\text { T3 }\end{array}$ & $\begin{array}{c}\text { Core } \\
\text { T8 }\end{array}$ \\
\hline 1 & 7.1 & 7.6 & 5.7 & 4.6 \\
\hline 3 & 7.5 & 8.6 & 5.8 & 5.4 \\
\hline 5 & 6.9 & 8.1 & 4.8 & 4.9 \\
\hline 7 & 6.7 & 6.8 & 4.8 & 4.3 \\
\hline 9 & 7.2 & 7.1 & 4.5 & 5.4 \\
\hline 15 & 7.1 & 8.9 & 4.8 & 5.1 \\
\hline 21 & 7.5 & 7.5 & 4.4 & 5.1 \\
\hline 25 & 7.3 & 9.9 & 4.2 & 4.5 \\
\hline 31 & 6.9 & 5.1 & 4.9 & 4.4 \\
\hline 35 & 6.8 & 9.5 & 4.4 & 3.9 \\
\hline 41 & 6.6 & 7.4 & 4.5 & 3.6 \\
\hline 45 & 6.9 & 6.2 & 3.8 & 3.9 \\
\hline 51 & 6.7 & 5.5 & 3.9 & 4.2 \\
\hline 61 & 8.1 & 5.5 & 3.0 & 3.5 \\
\hline 71 & 8.3 & 0.7 & 3.7 & 3.0 \\
\hline 81 & 6.8 & 3.2 & 1.8 & 2.4 \\
\hline 91 & 7.4 & 0.8 & 1.5 & 2.5 \\
\hline 101 & 7.0 & 1.4 & 1.6 & 2.6 \\
\hline 111 & 6.4 & 0.6 & 1.6 & 1.4 \\
\hline 121 & 7.6 & 2.5 & 1.3 & 2.7 \\
\hline 131 & 7.0 & 4.8 & 1.2 & 2.6 \\
\hline 141 & 5.8 & 5.0 & 1.0 & 2.1 \\
\hline 151 & 5.4 & 4.4 & 1.3 & 2.2 \\
\hline 161 & 7.6 & 3.9 & 1.5 & 2.3 \\
\hline 171 & 6.3 & 4.9 & 1.9 & 2.2 \\
\hline 181 & 6.4 & 5.5 & 2.0 & 2.2 \\
\hline 197 & 6.8 & 5.6 & 1.9 & 2.2 \\
\hline Maximum & 8.3 & 9.9 & 5.8 & 5.4 \\
\hline Minimum & 5.4 & 0.6 & 1.0 & 1.4 \\
\hline Mean & 7.0 & 5.4 & 3.2 & 3.4 \\
\hline SD & 0.6 & 2.7 & 1.6 & 1.2 \\
\hline
\end{tabular}

The depth plots for the analyzed chemical elements are presented in Fig. 4. This figure shows that concentrations of $\mathrm{Ag}, \mathrm{Cu}, \mathrm{P}, \mathrm{Pb}, \mathrm{S}$ and $\mathrm{Zn}$ are relatively low in the lower section of the analyzed cores and increase significantly in the upper
$80 \mathrm{~cm}$. Calcium contents have an opposed pattern, decreasing in the upper section of these cores. These trends are more marked in core $\mathrm{T} 8$, where $\mathrm{Ag}, \mathrm{Ca}, \mathrm{Cu}, \mathrm{P}, \mathrm{S}$ and $\mathrm{Zn}$ reach higher maximum and mean concentrations than core T3. Depth plots of CF of the analyzed elements $\mathrm{Ag}, \mathrm{Ca}, \mathrm{Cu}$, $\mathrm{P}, \mathrm{Pb}, \mathrm{S}$ and $\mathrm{Zn}$ ) along the cores $\mathrm{T} 3$ and $\mathrm{T} 8$ also evidence similar trends (Fig. 5).

Tab. 2. Results of ${ }^{206} \mathrm{~Pb} /{ }^{207} \mathrm{~Pb}$ along the cores $\mathrm{T} 3$ and $\mathrm{T} 8$.

\begin{tabular}{|c|c|c|}
\hline \multirow{2}{*}{$\begin{array}{l}\text { Depth } \\
\text { (cm) }\end{array}$} & Core T3 & Core $\mathrm{T} 8$ \\
\hline & ${ }^{206} \mathrm{~Pb} /{ }^{207} \mathrm{~Pb}$ & ${ }^{206} \mathrm{~Pb} /{ }^{207} \mathrm{~Pb}$ \\
\hline 1 & 1.18 & 1.16 \\
\hline 5 & 1.16 & 1.16 \\
\hline 9 & 1.15 & $\ldots$ \\
\hline 13 & 1.16 & 1.16 \\
\hline 17 & 1.17 & 1.16 \\
\hline 21 & 1.17 & 1.16 \\
\hline 25 & 1.17 & 1.15 \\
\hline 29 & 1.18 & 1.16 \\
\hline 33 & 1.15 & 1.17 \\
\hline 37 & 1.17 & 1.16 \\
\hline 41 & 1.16 & 1.17 \\
\hline 45 & 1.18 & $\ldots$ \\
\hline 49 & 1.17 & 1.16 \\
\hline 53 & 1.20 & 1.15 \\
\hline 57 & 1.19 & 1.14 \\
\hline 61 & 1.20 & 1.17 \\
\hline 65 & 1.17 & 1.17 \\
\hline 69 & 1.19 & 1.17 \\
\hline 81 & 1.19 & 1.18 \\
\hline 97 & 1.20 & 1.18 \\
\hline 145 & 1.20 & 1.20 \\
\hline 197 & 1.20 & 1.20 \\
\hline Maximum & 1.20 & 1.20 \\
\hline Minimum & 1.15 & 1.14 \\
\hline Mean & 1.18 & 1.17 \\
\hline
\end{tabular}

\subsection{Statistical results}

The results of the PCA based on ${ }^{206} \mathrm{~Pb} / 207 \mathrm{~Pb}$ values and TOC and elemental concentrations (Ag, $\mathrm{Ca}, \mathrm{Cu}, \mathrm{P}, \mathrm{Pb}, \mathrm{S}$ and $\mathrm{Zn})$ in cores T3 and T8 is presented in Fig. 6 and Table 4. Factor $1(71 \%)$ and Factor $2(14 \%)$ explain most part of data variability (85\%). The biplot of Factor 1 versus Factor 2 evidence that, in both cores ${ }^{206} \mathrm{~Pb} /{ }^{207} \mathrm{~Pb}$ and $\mathrm{Ca}$ (Group I) are opposed to the enrichment of $\mathrm{Ag}, \mathrm{Cu}, \mathrm{P}, \mathrm{Pb}, \mathrm{S}$ and $\mathrm{Zn}$ and TOC (Group II).

This relationship is also evidenced by Pearson correlations (Appendix 2): the analyzed chemical elements have significant positive correlations with each other and TOC, in both cores, except with $\mathrm{Ca}$ and ${ }^{206} \mathrm{~Pb} /{ }^{207} \mathrm{~Pb}$ values. The depth plots presented in Figs. 3-5 and the statistical 
results evidence that core $\mathrm{T} 8 \mathrm{~h}$ has similar geochemical results in the analyzed section $(0-197 \mathrm{~cm})$ to core T3.

\section{Discussion}

The accumulation rate recorded in core T3 $\left(0.67 \mathrm{~cm} \mathrm{yr}^{-1}\right)$ is the same determined by Baptista Neto et al. (2013) in a core collected near this one and is higher than that reported by Amador (1980) and Godoy et al. (1998), of $0.19 \mathrm{~cm} \mathrm{yr}^{-1}$, due to its location near the river Iriri outflow and others rivers mouth at the Apa de Guapimirim. This accumulation rate is also higher than that estimated by Peixoto (2005) for Guarapina lagoon (in Rio de Janeiro State) of $0.27 \mathrm{~cm} \mathrm{yr}^{-1}$. Amador (1980) reported sediment accumulation rates for two periods comparing nautical charts, for the bathymetric range of 5 to $10 \mathrm{~m}$ (close to the area where the core T8 was collected). This author calculated silting rates of $15.1 \mathrm{~cm} .100$ $\mathrm{yrs}^{-1}$ and $41.6 \mathrm{~cm} .100 \mathrm{yrs}^{-1}$ for the periods 1849-1922 and 1938-1962, respectively. These values indicate a tendency to increase the accumulation rate toward the recent.

Tab. 3. Elemental concentrations (Ag, $\mathrm{Ca}, \mathrm{Cu}, \mathrm{P}, \mathrm{Pb}, \mathrm{S}$ and $\mathrm{Zn})$ in cores $\mathrm{T} 3$ and $\mathrm{T} 8$.

\begin{tabular}{|c|c|c|c|c|c|c|c|}
\hline \multicolumn{8}{|c|}{ Core T3 } \\
\hline \multirow{2}{*}{$\begin{array}{l}\text { Depth } \\
\text { (cm) }\end{array}$} & Ag & $\mathrm{Ca}$ & $\mathrm{Cu}$ & $\mathbf{P}$ & $\mathrm{Pb}$ & $\mathbf{S}$ & $\mathrm{Zn}$ \\
\hline & $\mathrm{mg} \mathrm{kg}^{-1}$ & $\%$ & $\mathrm{mg} \mathrm{kg}^{-1}$ & $\%$ & $\mathrm{mg} \mathrm{kg}^{-1}$ & $\%$ & $\mathrm{mg} \mathrm{kg}^{-1}$ \\
\hline 1 & 1.60 & 0.62 & 70 & 0.132 & 62 & 1.21 & 238 \\
\hline 5 & 0.70 & 0.41 & 61 & 0.100 & 60 & 1.61 & 232 \\
\hline 9 & 0.70 & 0.49 & 65 & 0.078 & 63 & 1.30 & 207 \\
\hline 13 & 0.80 & 0.64 & 60 & 0.083 & 65 & 1.41 & 200 \\
\hline 17 & 0.70 & 0.50 & 67 & 0.080 & 65 & 1.32 & 210 \\
\hline 21 & 0.50 & 0.54 & 59 & 0.077 & 65 & 1.17 & 190 \\
\hline 25 & 0.50 & 0.62 & 70 & 0.080 & 70 & 1.25 & 202 \\
\hline 29 & 0.29 & 0.44 & 39 & 0.075 & 65 & 1.18 & 178 \\
\hline 33 & 0.60 & 0.64 & 36 & 0.083 & 73 & 1.11 & 183 \\
\hline 37 & 0.40 & 0.73 & 61 & 0.082 & 73 & 1.02 & 194 \\
\hline 41 & 0.29 & 0.72 & 46 & 0.077 & 64 & 0.92 & 169 \\
\hline 45 & 0.29 & 1.74 & 25 & 0.073 & 52 & 0.91 & 106 \\
\hline 49 & 0.29 & 1.51 & 21 & 0.078 & 45 & 0.78 & 107 \\
\hline 53 & 0.29 & 1.60 & 19 & 0.079 & 39 & 0.86 & 97 \\
\hline 57 & 0.30 & 1.60 & 18 & 0.073 & 30 & 0.76 & 82 \\
\hline 61 & 0.29 & 1.41 & 15 & 0.077 & 27 & 0.77 & 90 \\
\hline 65 & 0.29 & 1.87 & 21 & 0.078 & 40 & 0.75 & 107 \\
\hline 69 & 0.29 & 1.24 & 16 & 0.075 & 33 & 0.80 & 94 \\
\hline 81 & 0.29 & 1.72 & 15 & 0.072 & 16 & 0.93 & 83 \\
\hline 97 & 0.40 & 1.65 & 12 & 0.069 & 17 & 0.84 & 82 \\
\hline 145 & 0.29 & 1.52 & 16 & 0.067 & 16 & 0.82 & 79 \\
\hline 197 & 0.29 & 2.30 & 12 & 0.069 & 16 & 0.99 & 71 \\
\hline Maximum & 1.60 & 2.30 & 70 & 0.132 & 73 & 1.61 & 238 \\
\hline Minimum & 0.29 & 0.41 & 12 & 0.067 & 16 & 0.75 & 71 \\
\hline Medium & 0.47 & 1.11 & 37 & 0.080 & 48 & 1.03 & 146 \\
\hline \multicolumn{8}{|c|}{ Core T8 } \\
\hline \multirow{2}{*}{$\begin{array}{l}\text { Depth } \\
\text { (cm) }\end{array}$} & Ag & $\mathrm{Ca}$ & $\mathrm{Cu}$ & $\mathbf{P}$ & $\mathrm{Pb}$ & $\mathbf{S}$ & $\mathrm{Zn}$ \\
\hline & $\mathrm{mg} / \mathrm{kg}$ & $\%$ & $\mathrm{mg} / \mathrm{kg}$ & $\%$ & $\mathrm{mg} / \mathrm{kg}$ & $\%$ & $\mathrm{mg} / \mathrm{kg}$ \\
\hline 1 & 1.60 & 1.36 & 84 & 0.1510 & 70 & 1.54 & 229 \\
\hline 5 & 1.60 & 1.10 & 73 & 0.1470 & 58 & 1.37 & 225 \\
\hline 13 & 1.50 & 0.78 & 75 & 0.1210 & 52 & 1.50 & 238 \\
\hline 17 & 1.50 & 0.82 & 60 & 0.1080 & 49 & 1.61 & 218 \\
\hline 21 & 1.80 & 0.76 & 68 & 0.1210 & 56 & 1.60 & 245 \\
\hline 25 & 1.60 & 0.77 & 74 & 0.1140 & 54 & 1.65 & 248 \\
\hline
\end{tabular}


Table 3 (cont.). Elemental concentrations (Ag, Ca, Cu, P, Pb, S and $\mathrm{Zn}$ ) in cores T3 and T8.

\begin{tabular}{|c|c|c|c|c|c|c|c|}
\hline \multicolumn{8}{|c|}{ Core T8 } \\
\hline \multirow{2}{*}{$\begin{array}{l}\text { Depth } \\
(\mathrm{cm})\end{array}$} & Ag & $\mathrm{Ca}$ & $\mathrm{Cu}$ & $\mathbf{P}$ & $\mathrm{Pb}$ & $\mathbf{S}$ & $\mathrm{Zn}$ \\
\hline & $\mathrm{mg} / \mathrm{kg}$ & $\%$ & $\mathrm{mg} / \mathrm{kg}$ & $\%$ & $\mathrm{mg} / \mathrm{kg}$ & $\%$ & $\mathrm{mg} / \mathrm{kg}$ \\
\hline 29 & 1.50 & 0.85 & 66 & 0.1040 & 52 & 1.54 & 234 \\
\hline 33 & 1.70 & 1.09 & 72 & 0.1040 & 62 & 1.53 & 236 \\
\hline 37 & 1.60 & 0.75 & 73 & 0.1050 & 55 & 1.68 & 239 \\
\hline 41 & 1.00 & 0.41 & 68 & 0.0930 & 52 & 1.63 & 236 \\
\hline 49 & 1.10 & 0.67 & 72 & 0.1040 & 61 & 1.70 & 243 \\
\hline 53 & 0.90 & 0.93 & 62 & 0.1080 & 57 & 1.65 & 218 \\
\hline 57 & 0.80 & 0.90 & 39 & 0.0880 & 64 & 1.50 & 191 \\
\hline 61 & 0.60 & 1.05 & 41 & 0.0940 & 65 & 1.65 & 186 \\
\hline 65 & 0.60 & 1.15 & 42 & 0.0890 & 64 & 1.55 & 178 \\
\hline 69 & 0.60 & 1.36 & 46 & 0.0850 & 66 & 1.21 & 140 \\
\hline 81 & 0.29 & 1.72 & 15 & 0.0770 & 22 & 1.00 & 84 \\
\hline 97 & 0.40 & 2.49 & 13 & 0.0710 & 17 & 1.00 & 79 \\
\hline 145 & 0.29 & 1.89 & 16 & 0.0670 & 15 & 1.19 & 73 \\
\hline 197 & 0.50 & 2.35 & 11 & 0.0700 & 14 & 1.15 & 68 \\
\hline Maximum & 1.80 & 2.49 & 84 & 0.1510 & 70 & 1.70 & 248 \\
\hline Minimum & 0.29 & 0.41 & 11 & 0.0670 & 14 & 1.00 & 68 \\
\hline Medium & 1.07 & 1.16 & 54 & 0.1011 & 50 & 1.46 & 190 \\
\hline
\end{tabular}

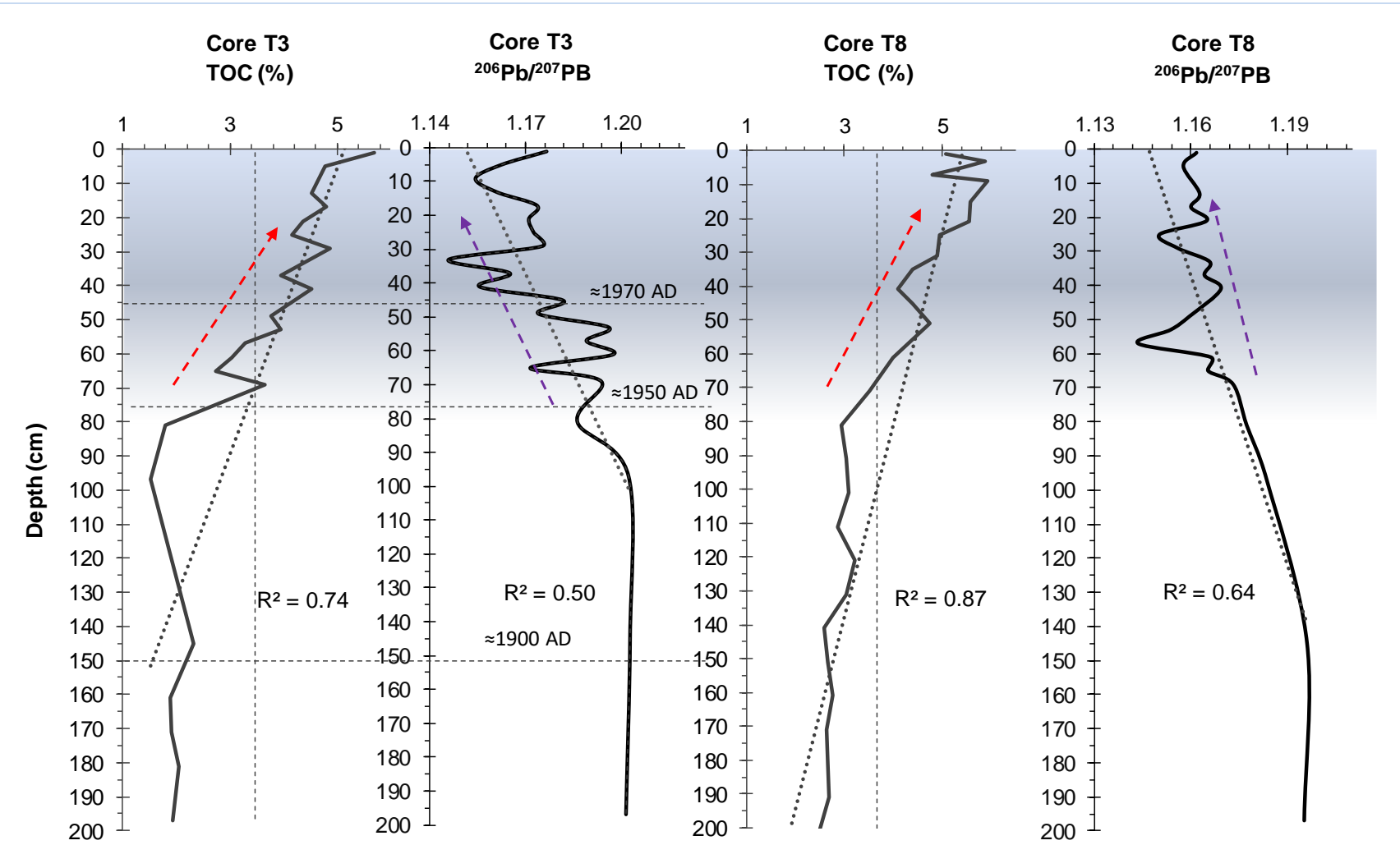

Fig. 3. Depth plots of TOC $(\%)$ and ${ }^{206} \mathrm{~Pb} /{ }^{207} \mathrm{~Pb}$ ratio along the cores T3 and T8. Estimated ages based on ${ }^{210} \mathrm{~Pb}$ geochronology are presented. AD - Anno Domini. The trend lines and respective $\mathrm{R}^{2}$ are presented, as well as the mean value for the TOC depth plots are presented in both cores. The section between $80-0 \mathrm{~cm}$ has been shaded; it is characterized by the sharp increase in TOC values and decrease of ${ }^{206} \mathrm{~Pb} /{ }^{207} \mathrm{~Pb}$ ratios; these trends also were marked with arrows. 

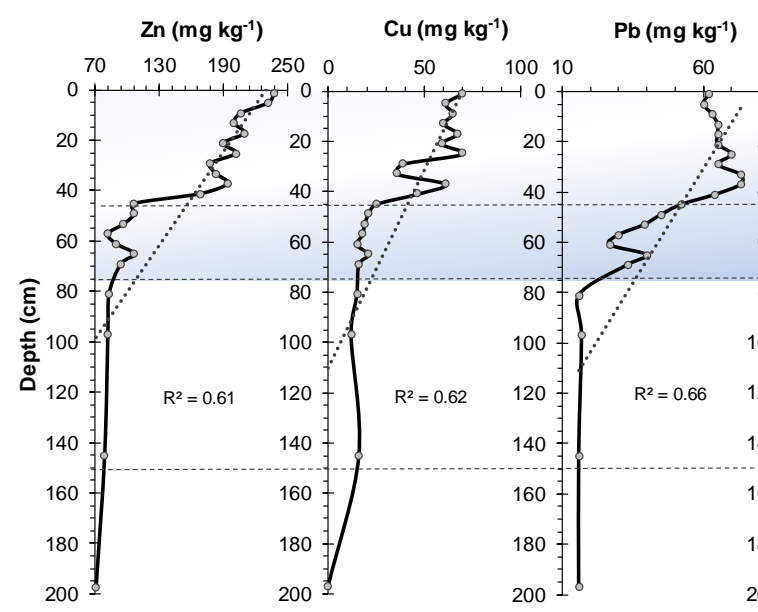

\section{Core T3}

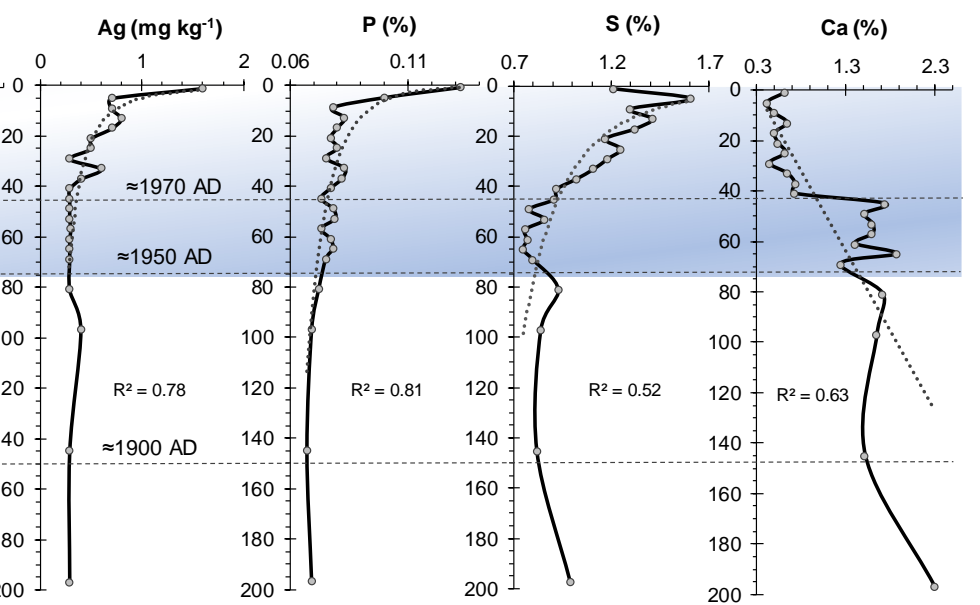

\section{Core T8}
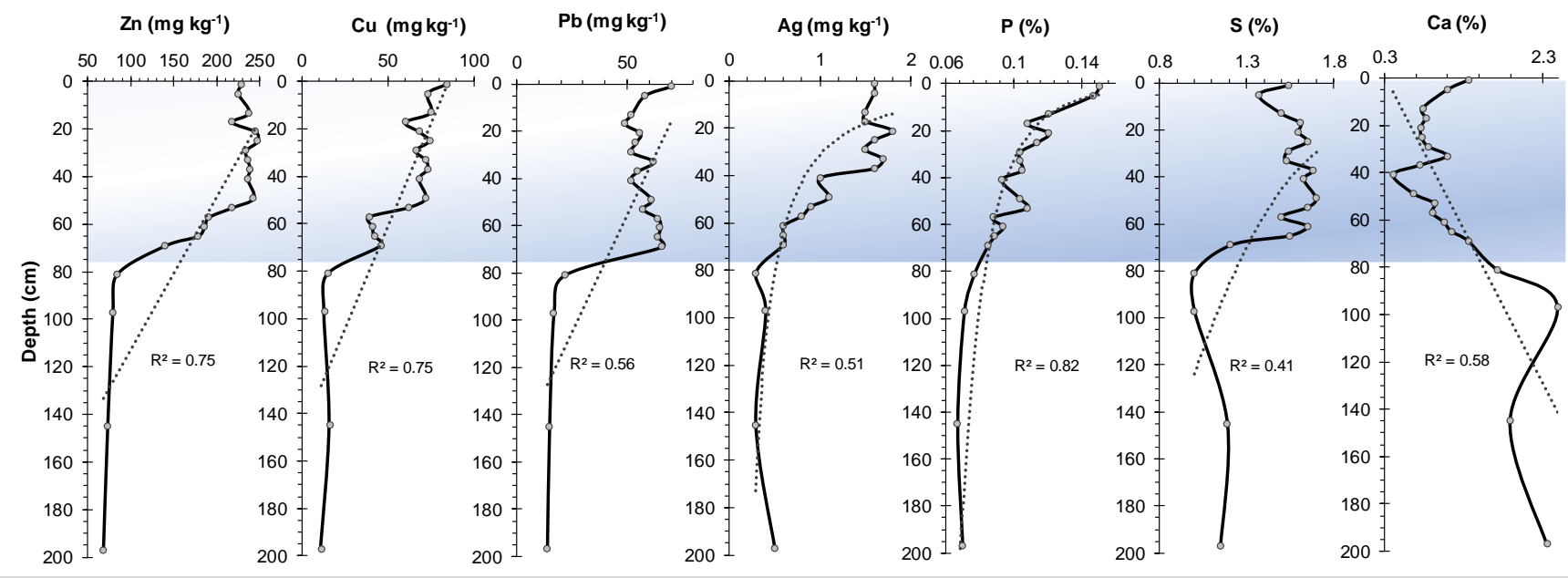

Fig. 4. Depth plots of elemental concentrations (Ag, Ca, Cu, P, Pb, S and $\mathrm{Zn}$ ) along the cores T3 and T8. Estimated ages based on ${ }^{210} \mathrm{~Pb}$ geochronology are presented. $\mathrm{AD}-$ Anno Domini. The regression line and respective $\mathrm{R}^{2}$ value are also presented. The section between 80-0 $\mathrm{cm}$ has been shaded to mark the sharp increase of $\mathrm{Ag}, \mathrm{Cu}, \mathrm{P}, \mathrm{Pb}, \mathrm{S}$ and $\mathrm{Zn}$ concentrations and decrease of $\mathrm{Ca}$ concentrations.

The analyzed cores are located in an area of low hydrodynamism (Amador, 1980), where presently tidal currents are not intense, favoring the accumulation of finegrained sediments enriched in organic materials (Delavy et al., 2016; Alves Martins et al., 2018).

Both cores (T3 and T8) have similar distribution patterns of TOC and elemental concentrations and ${ }^{206} \mathrm{~Pb} /{ }^{207} \mathrm{~Pb}$ values. This similarity indicates that both cores although located in distinct areas of Guanabara Bay record the same reality.

\subsection{Long-term trends of eutrophication in the} Northern/Northeast Area of Guanabara Bay

The analyzed cores have TOC contents ranging from 1 to $6 \%$ (Table 1). Several studies have shown that organic matter contents in Guanabara Bay vary inversely with the increasing of sediment grain size, that is, where the percentage of sand and gravel tends to decrease towards the interior of the bay, the percentage of organic material tends to increase (e.g. Catanzaro et al., 2004; Alves Martins et al., 2018). According to Catanzaro et al. (2004) percentages of TOC $<1 \%$ occur in the entrance and central channel of GB, associated to coarser grained sediments, stronger tidal currents and, consequently, greater water oxygenation, which favor organic matter degradation. The high levels of organic matter, such as those presented in the inner part of the bay and in more sheltered areas, are in general related to reducing sedimentary conditions and consequently lower rate of degradation (e.g. Delavy et al., 2016; Alves Martins et al., 2018).

As shown in Fig. 3, TOC contents increased significant and continuously since the 50's in core T3. Similar trend is observed in core $\mathrm{T} 8$, corresponding probably to the same period. This trend was attributed to the growing process of eutrophication in protected environments due to anthropic action, which has been causing a progressive and marked environmental degradation. 
Phosphorus is a nutrient which enhances primary production (Pace and Lovett, 2013; Misailidis et al., 2018). The increase in $\mathrm{P}$ contents associated with the rising of TOC (Fig. 6), especially since the 50 's, may be related to agricultural fertilizers and launching of domestic sewage in GB, enhancing the primary productivity in this ecosystem.

The opposite pattern of $\mathrm{Ca}$ and TOC contents should indicate carbonate dissolution (poor preservation) due to the production of acids following organic matter degradation (e.g. Delavy et al., 2016; Martins et al., 2016 a, b). On the other hand, in coastal environments mollusks and foraminifera with carbonate shells and tests are relatively abundant. The reduction of $\mathrm{Ca}$ values may also indicate a decline in the presence of these organisms due to processes of oxygen depletion in the bottom water and sediment, due to eutrophication processes (e.g. Delavy et al., 2016; Baptista Neto et al., 2017). In these sediments, it is frequent to
RESEARCH PAPER

observe the presence of living foraminifera with poorly calcified and dissolved tests (Martins et al., 2016 a, b). This means that these organisms have difficulty of calcify their shells and tests in this environment. The presence of high sedimentary organic matter content is being a stressing and unfavorable factor for the life of these protozoans (Martins et al., $2016 \mathrm{a}, \mathrm{b}$ ) and mollusks as well.

Positive correlations between TOC and S, may suggest the production of sulfides. Pyrite was found in the sediments of the inner area of Guanabara Bay, related to initial processes of diageneses (Pennafirme et al., 2015). Another effect of high accumulation of organic matter in the inner area of GB is the presence of gas seeping (Catanzaro et al., 2004; Delavy et al., 2016). The release of biogenic methane from the sediments was identified in some areas of the northern region of GB (Catanzaro et al., 2004; Delavy et al., 2016).

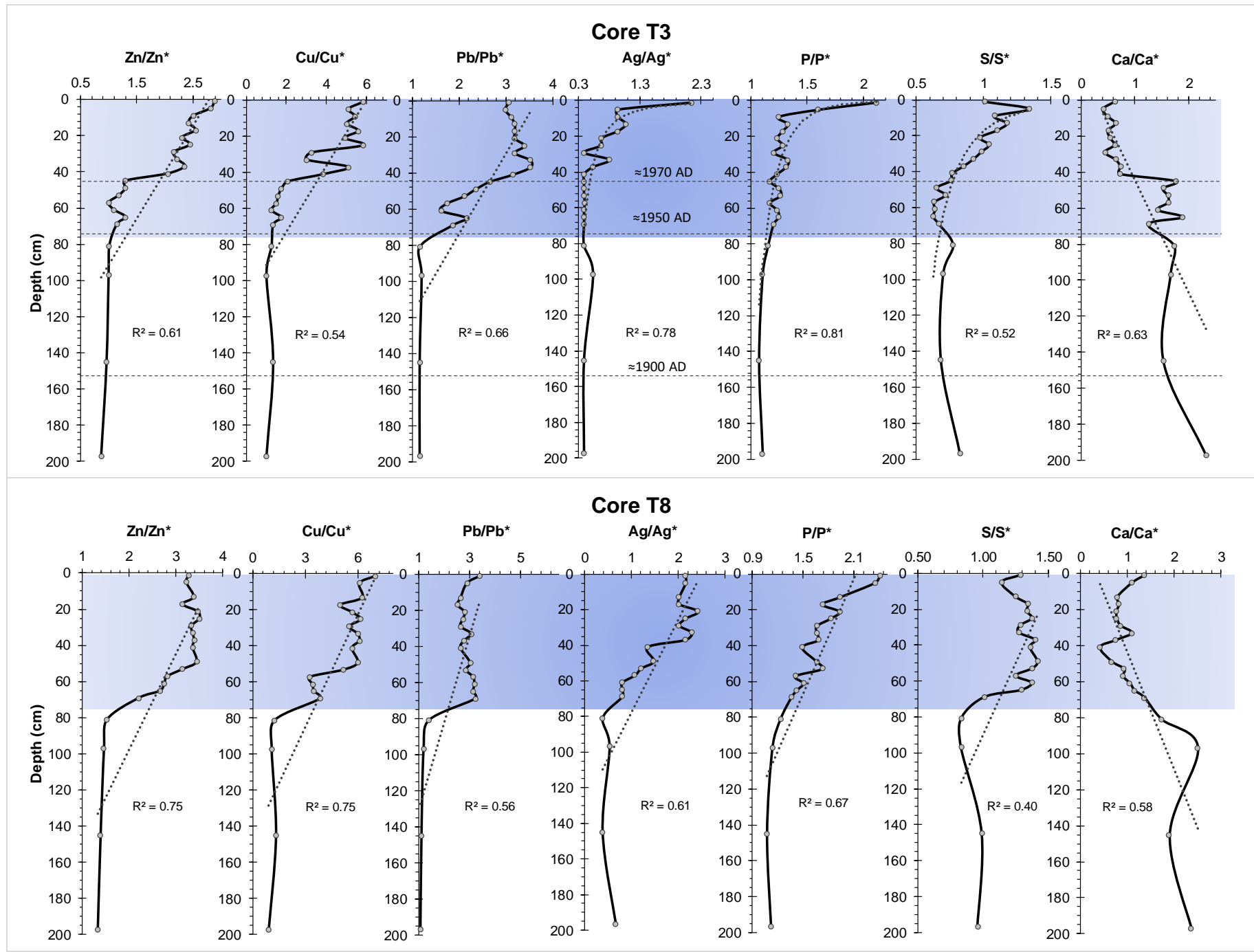

Fig. 5. Depth plots of $\mathrm{CF}$ of the analyzed elements (Ag, Ca, Cu, P, Pb, S and $\mathrm{Zn}$ ) along the cores T3 and T8. Estimated ages based on ${ }^{210} \mathrm{~Pb}$ geochronology are presented for core T3. AD - Anno Domini. The regression line and the respective $\mathrm{R}^{2}$ value are also presented. The section between $80-0 \mathrm{~cm}$, where the increase or decrease of several CF values is more prominent, has been shaded. 


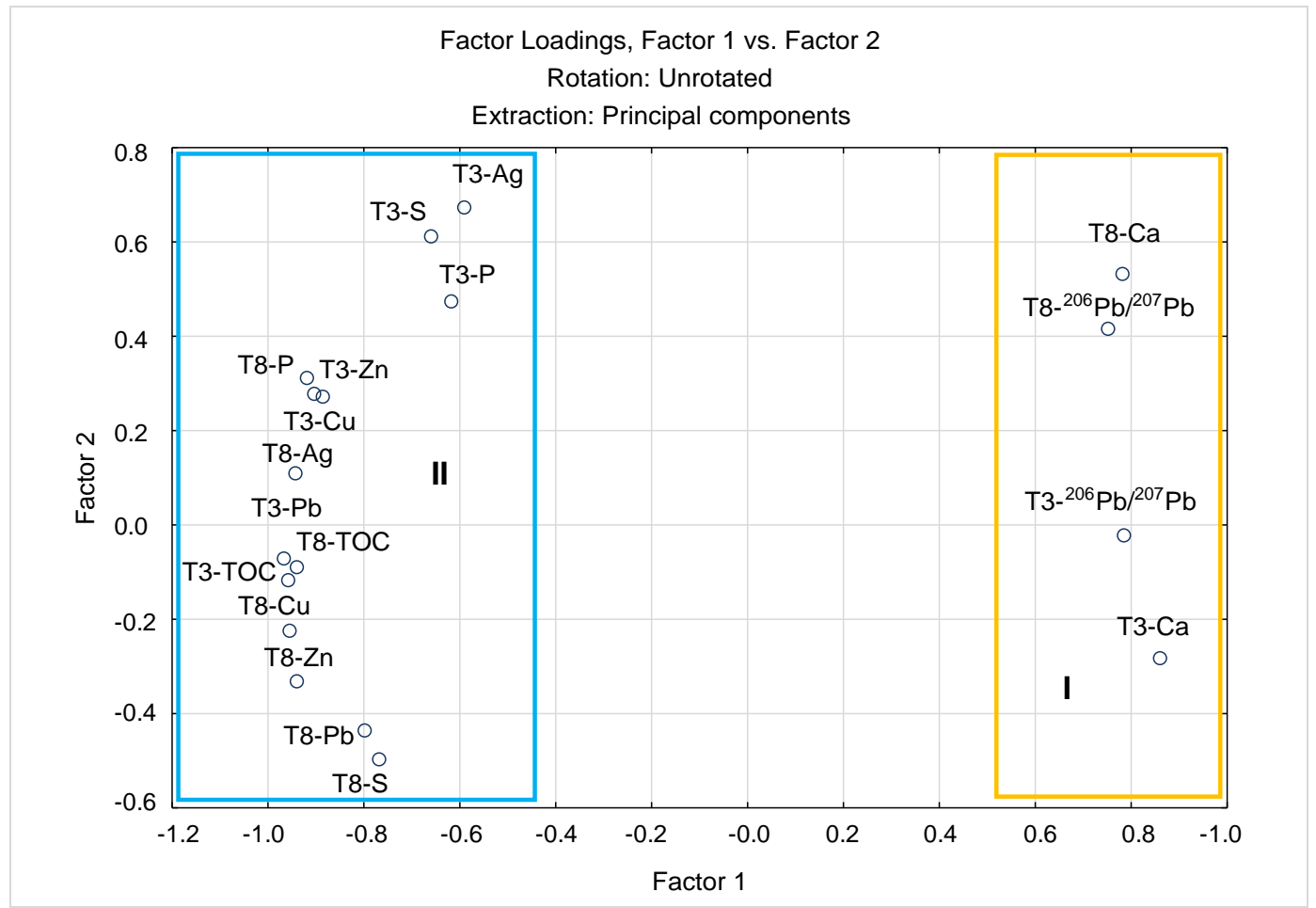

Fig. 6. Biplot of Factor 1 against the Factor 2 of PCA based on TOC, ${ }^{206} \mathrm{~Pb} /{ }^{207} \mathrm{~Pb}$ and $(\mathrm{Ag}, \mathrm{Ca}, \mathrm{Cu}, \mathrm{P}, \mathrm{Pb}, \mathrm{S}$ and $\mathrm{Zn})$ in cores $\mathrm{T} 3$ and T8.

\subsection{Anthropic impact in the Northern/Northeast Area of Guanabara Bay}

Depth plots of $\mathrm{Ag}, \mathrm{Cu}, \mathrm{P}, \mathrm{Pb}$ and $\mathrm{Zn}$ concentrations as well as the CF values (Fig. 5) reveals continuous increases of these metals in the upper sections of cores T3 and T8. The increase in both cores of $\mathrm{Cu}$ and $\mathrm{Zn}$, for instance, is positively correlated with $\mathrm{Pb}$ (Fig. 7). Similar trends were also observed by Baptista Neto et al. (2013, 2017).

The PCA results presented in Fig. 6 indicate that the metals increase, namely $\mathrm{Pb}$, in both cores is followed by the decreasing of ${ }^{206} \mathrm{~Pb} /{ }^{207} \mathrm{~Pb}$. The same is indicated by the biplots presented in Fig. 7. The range of ${ }^{206} \mathrm{~Pb} /{ }^{207} \mathrm{~Pb}$ values presented in this work for cores T3 and T8 (Fig. 8) were compared with that obtained in several investigations, such as Geraldes et al. (2006), in addition to the results obtained by Bollhöfer and Rosman (2000), Aily (2001), Moura et al. (2004), Moraes et al. (2004), Gioia et al. (2006) and Saliba et al. (2011). Geraldes et al. (2006) and Saliba et al. (2011) analyzed several surface bottom sediment samples spread along the innermost area of GB, as well as in Suruí and Magé rivers, thus encompassing our area.

According to the information compiled in Fig. 8, rocks and products of mining activity are characterized by lower ${ }^{206} \mathrm{~Pb} /{ }^{207} \mathrm{~Pb}$ values. Based on the results presented in Fig. 9 the anthropic activities left a marked influence characterized by increased TOC and potentially toxic metals concentrations mostly since the second half of the $20^{\text {th }}$ century, which agree with the observations of Baptista Neto et al. (2013). Thus, Guanabara Bay, which receives the sediment load from its boundary basin since it functions as a natural space for sediments accommodation, began to receive a much higher sediment load due to anthropic interventions (Baptista Neto et al., 2017).

The occupation of the surroundings and the islands of the Guanabara Bay, characterized by the removal of much of the natural vegetation including that of the Atlantic forest and mangroves may have caused this effect, namely the landfill, both in the islands for the construction of airports, and in the waterfront, such as those carried out from Caju to Copacabana, between 1902 and 1906, and from the 1950s onwards for the construction of Avenida Brazil, Flamengo embankment, Rio-Niterói bridge, Niterói-Manilha highway and Red Line. The filling and retreatment of some river channels, among other interventions, were formally implemented with the "sanitarista" conception in the $18^{\text {th }}$ century and intensified since the beginning of the $20^{\text {th }}$ century. The purpose of such interventions would be to provide support for urban and industrial expansion. However, such expansions eventually became disorganized due to population growth on a geometric scale.

In addition, resulting from the expansion of activities in its surroundings GB also started to receive an increase of domestic waste and sewage and industrial effluents and products, namely mining materials applied in industrial goods as well as oil, metals and organic load (as evidenced by the results of this work; Figs. 3, 4, 5, 7, 9). 

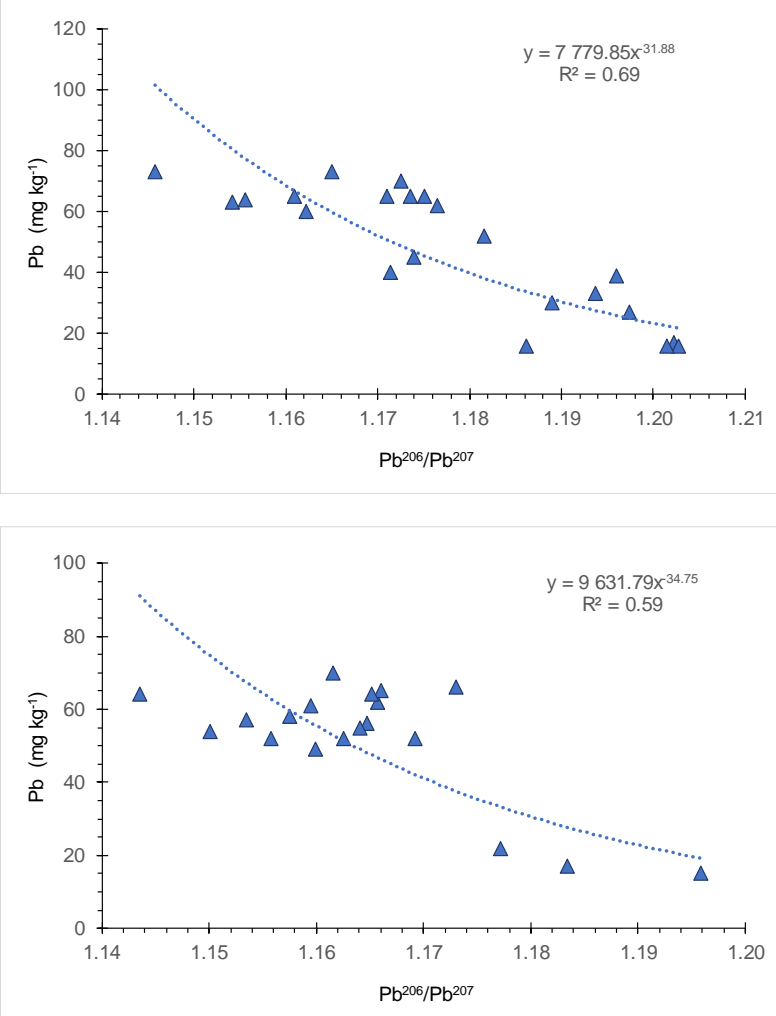

Core T3

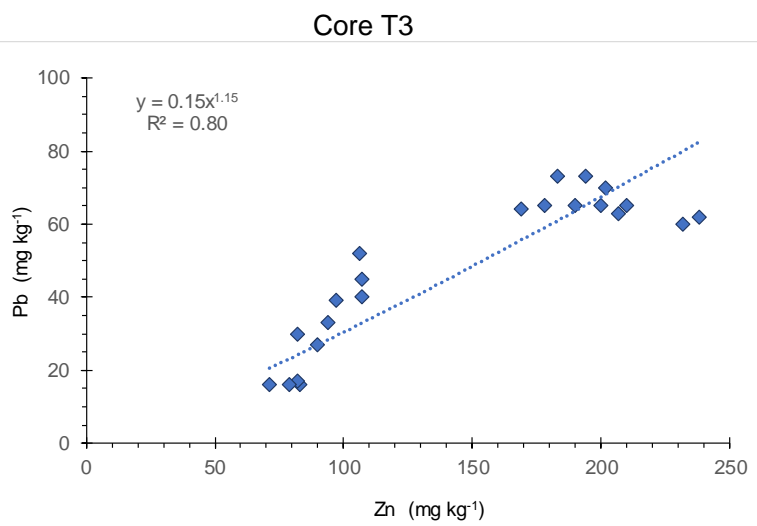

Core T8

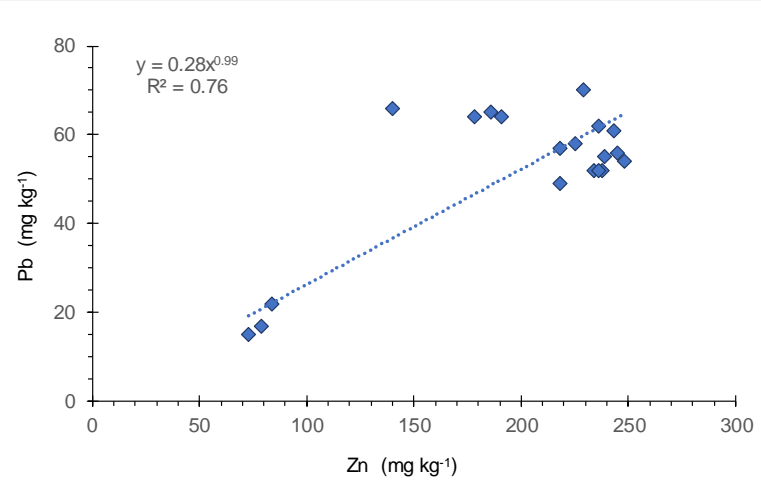

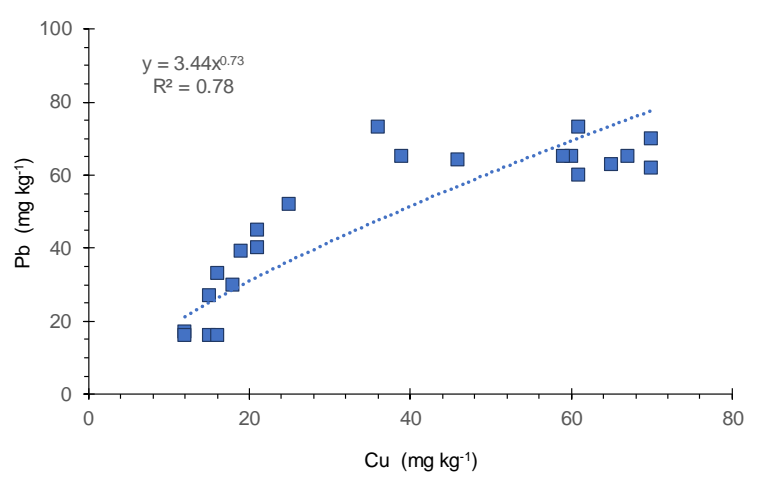

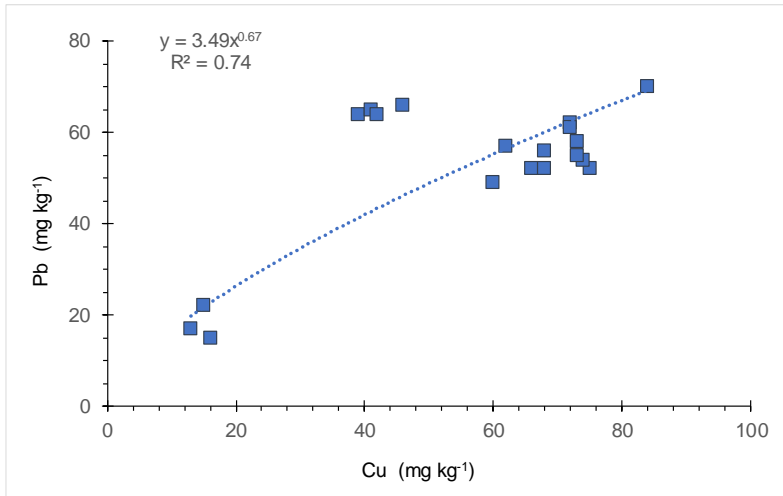

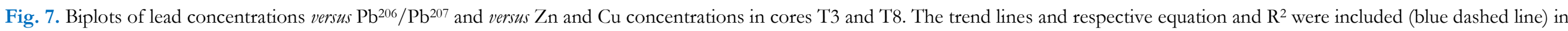
each graphic. 


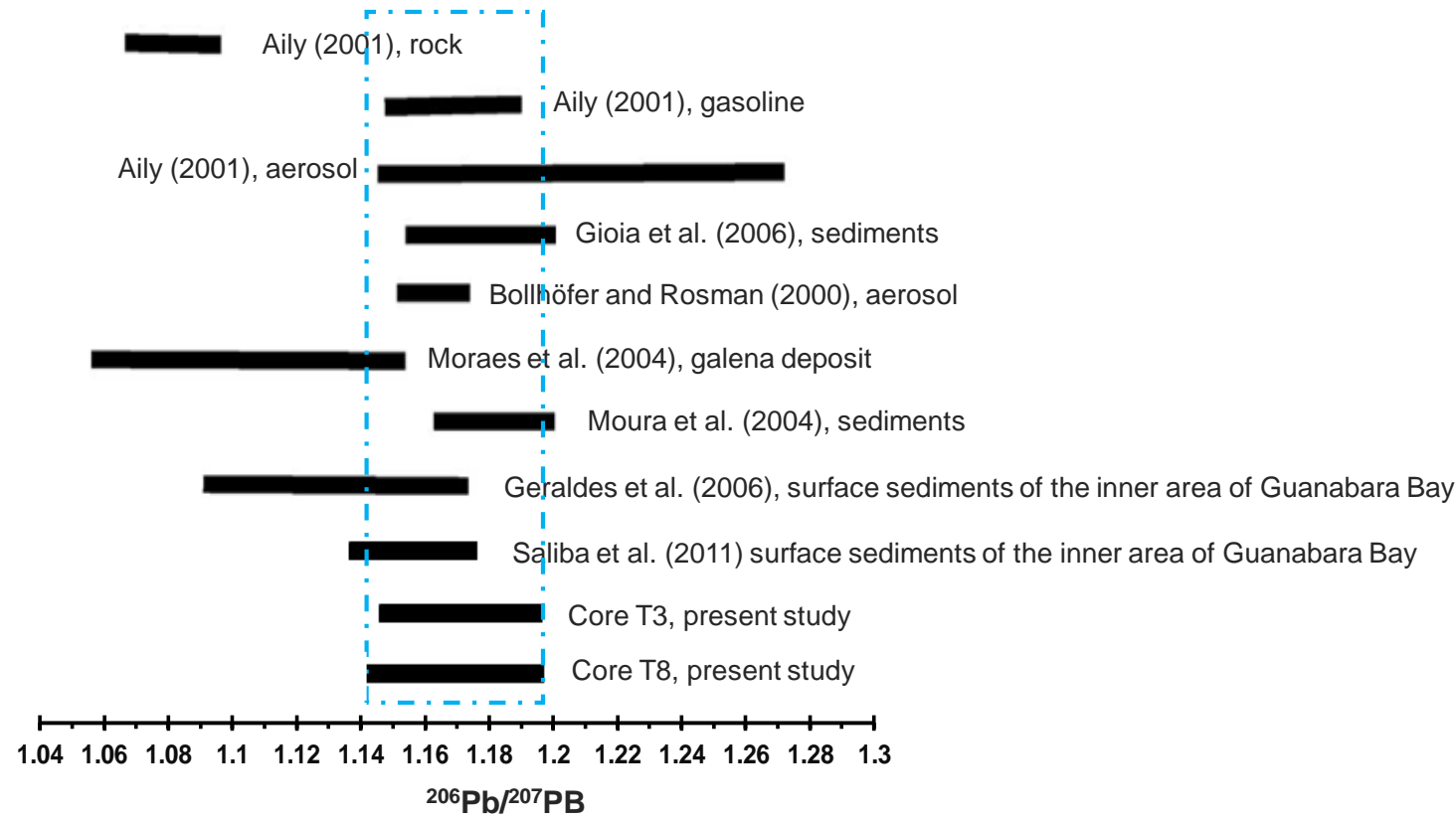

Fig. 8. Range of values of ${ }^{206} \mathrm{~Pb} /{ }^{207} \mathrm{~Pb}$ noticed in several investigations, including data of this work.

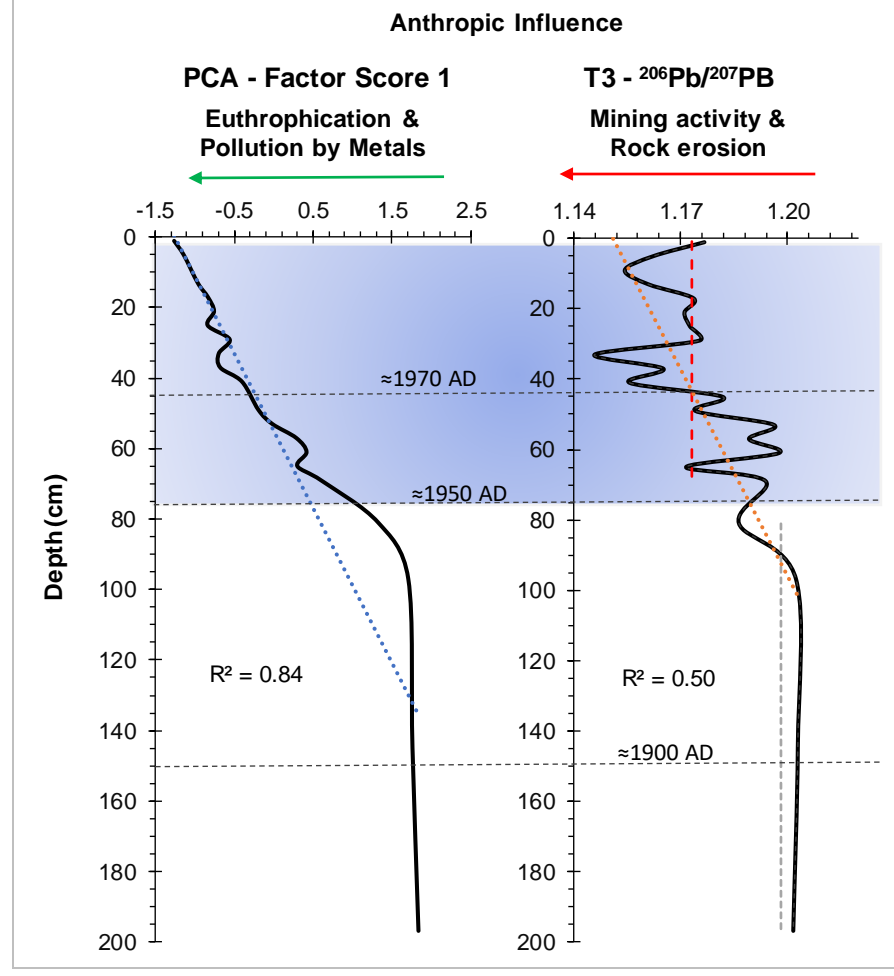

Fig. 9. Depth plots of: PCA Factor Score 1 and ${ }^{206} \mathrm{~Pb} /{ }^{207} \mathrm{~Pb}$ isotopic ratios along the cores $\mathrm{T} 3$ and $\mathrm{T} 8$. The mean values of ${ }^{206} \mathrm{~Pb} /{ }^{207} \mathrm{~Pb}$ isotopic ratios in two sections (1-70 $\mathrm{cm}$ and $80-197$ $\mathrm{cm})$ the first section representing the last 100 years and the second one the previous period, of the cores $\mathrm{T} 3$ and $\mathrm{T} 8$ are presented at dashed in different colors for each section. The red arrows at the top of the figure result from the interpretation of the PCA results (relative to data of Table 4) and ${ }^{206} \mathrm{~Pb} /{ }^{207} \mathrm{~Pb}$ ratios (in association with data shown in Figs. 3, 5 and 8).
Tab. 4. Correlations between the analyzed variables and the Factor 1 and Factor 2 of the PCA (Fig. 6).

\begin{tabular}{|l|c|c|}
\hline \multicolumn{1}{|c|}{ Variables } & Factor 1 & Factor 2 \\
\hline T3-206Pb/207Pb & 0.78 & -0.02 \\
\hline T3-Ag & -0.59 & 0.67 \\
\hline T3-Ca & 0.86 & -0.28 \\
\hline T3-Cu & -0.91 & 0.28 \\
\hline T3-P & -0.62 & 0.47 \\
\hline T3-Pb & -0.97 & -0.07 \\
\hline T3-S & -0.66 & 0.61 \\
\hline T3-Zn & -0.92 & 0.31 \\
\hline T3-TOC & -0.96 & -0.11 \\
\hline T8-TOC & -0.94 & -0.09 \\
\hline T8-206Pb/207Pb & 0.75 & 0.42 \\
\hline T8-Ag & -0.94 & 0.11 \\
\hline T8-Ca & 0.78 & 0.53 \\
\hline T8-Cu & -0.96 & -0.22 \\
\hline T8-P & -0.89 & 0.27 \\
\hline T8-Pb & -0.80 & -0.43 \\
\hline T8-S & -0.77 & -0.49 \\
\hline T8-Zn & -0.94 & -0.33 \\
\hline Explained Variance & $\mathbf{0 . 7 1}$ & \\
\hline
\end{tabular}

According to Baptista Neto et al. (2006) and Potratz et al. (2019) the regions where cores T3 and T8 were collected are low polluted by metals in GB. However, changes in sedimentological characteristics, metal concentrations and stable isotopes of lead along the cores T3 and T8 evidence 
an increasing trend eutrophication and metal pollution in this region northern/northeast of Guanabara Bay clearly marked since the 50's, with another pulse after the 70's, related to anthropic activities.

\section{Conclusion}

Stable isotopes of lead, namely the ${ }^{207} \mathrm{~Pb} / 206 \mathrm{~Pb}$ results in cores T3 and T8 indicate that rocks erosion and mining products applied to industrial goods is a substantial source of pollution and lead released in Guanabara Bay. The increase of eutrophication and metal pollution evidenced in the results obtained in cores T3 and T8, is clearly related to anthropic activities. Deforestation and landfill and embankment engineering works, domestic and industrial effluents, large amount of waste and sewage released daily (including mining materials applied in industrial products, as well as oil, heavy metals, toxic substances and organic load) together with the restricted circulation are causing a steadily increasing of negative impact especially since the second half of the $20^{\text {th }}$ century. This negative impact affects not only the region of the Guapimirim Environmental Protected Area (known as Apa de Guapimirim), a mangrove fringe but also central northern area of Guanabara Bay, at north of Paquetá island which have been considered low polluted areas of this coastal system.

Appendices 1-2 are attached as supplementary materials (SM1-SM2) in: http://www.e-publicacoes.uerj.br/index.php/jse/article/view/45786

\section{Acknowledgment}

This investigation was supported by FAPERJ (Fundação de Amparo à Pesquisa do Estado do Rio de Janeiro; Grant E26/100.662/2007) and CNPq (Conselho Nacional de Desenvolvimento Científico e Tecnológico, Brazil; Grant 554449/2006-2). Mauro Geraldes thanks CNPq for the financial support (Grant 501710/2007-8). Virginia Martins and Mauro Geraldes also would like to thank the CnPQ for the research grants (process \# 301588/2016-3 and process \# 301470/2016-2, respectively) and the funding attributed to the project process \# 443662/2018-5.

\section{References}

Aily, C., 2001. Caracterização isotópica de Pb na atmosfera: um exemplo da cidade de São Paulo. MsD Thesis, Instituto de Geociências, Universidade de São Paulo, São Paulo, Brazil, 76 pp.

Alves Martins, M.V., Rodrigues, R., Pereira, E., Miranda, P., Laut, L., Belart, P., Villena, H.H., Geraldes, M.C., Mello e Sousa, S.H., Duleba, W., Bergamashi, S., 2018. Organic pollution in the NE Sector of Guanabara Bay (SE, Brazil). Journal of Sedimentary Environments 3 (3), 138-154. https://doi.org/10.12957/jse.2018.37826

Alves Martins, M.V., Zaaboub, N., Aleya, L., Frontalini, F., Pereira, E., Miranda, P., Mane, M., Rocha, F., Laut, L., El Bour, M. 2015. Environmental Quality Assessment of Bizerte Lagoon (Tunisia) Using Living Foraminifera Assemblages and a
Multiproxy Approach. PLoS ONE 10(9), e0137250. https://doi.org/10.1371/journal.pone.0137250

Amador, ES., 1997. Baía de Guanabara e ecossistemas periféricos - Homem e Natureza. Rio de Janeiro, Reproarte Gráfica e Editora, 529 p.

Amador, E.D.S., 1980. Assoreamento da Baía de Guanabara Taxas de Sedimentação. Anais da Academia Brasileira de Ciências 52 (4), 723-742.

Appleby, P.G., Oldfield, F., 1992. Application of lead-210 to sedimentation studies. In: Ivanovich, M. and Harmon, R.S., (Eds), Uranium Series Disequilibrium: Applications to Environmental Problems. $2^{\text {nd }}$ ed., Clarendon Press, p. 731-778.

Austin, S.A., 2005. Do radioisotopic clocks need repair? Testing the assumptions of isochron dating using $\mathrm{K}-\mathrm{Ar}, \mathrm{Rb}-\mathrm{Sr}, \mathrm{Sm}-\mathrm{Nd}$, and $\mathrm{Pb}-\mathrm{Pb}$ isotopes. In: Vardiman, L., Snelling, A.A. and Chaffin, E. F. (eds.), Chapter 5, Radioisotopes and the Age of the Earth, Volume II: Results of a Young-Earth Creationist Research Initiative, Institute for Creation Research, El Cajon, California, pp. 325-524.

Babinski, M., Ruiz, I.R., Aily, C., Yoshida, S.S., 2005. Concentrações e composições isotópicas de $\mathrm{Pb}$ na atmosfera da cidade de São Paulo. O que mudou entre 1999 e 2001? Workshop Internacional de Geologia Médica. Painel. http://www.cprm.gov.br/publique/media/Painel37.pdf. Accessed on 01.09.2019

Bacon, J.R., Farmer, J.G., Dunn, S.M., Graham, M.C., Vinogradoff, S.I., 2006. Sequential extraction combined with isotope analysis as a tool for the investigation of lead mobilisation in soils: Application to organic-rich soils in an upland catchment in Scotland. Environmental Pollution 141, 469-481. https://doi.org/10.1016/j.envpol.2005.08.067

Bacon, J.R., Jones, K.C., McGrath, S.P., Johnston, A.E., 1996. Isotopic character of lead deposited from the atmosphere at a grassland site in the United Kingdom since 1860. Environmental Science and Technology 30, 2511-2518.

Bacon, J.R., Berrow, M.L., Shand, C.A., 1995. Isotopic characterization of lead in the Scottish upland environment. International Journal of Environmental Analytical Chemistry 59, 253-264. https://doi.org/10.1016/j.envpol.2005.08.067

Baptista Neto, J.A., Barreto, C.F., Vilela, C.G., Fonseca, E.M., Melo, G.V., Barth, O.M., 2017. Environmental change in Guanabara Bay, SE Brazil, based in microfaunal, pollen and geochemical proxies in sedimentary cores. Ocean \& Coastal Management 143, 4-15

Baptista Neto, J.A., Peixoto, T.C.S., Smith, B.J., Mcalister, J.J., Patchineelam, S.M., Patchineelam, S.R., Fonseca, E.M., 2013. Geochronology and heavy metal flux to Guanabara Bay, Rio de Janeiro state: a preliminary study. Anais da Academia Brasileira de Ciências 85(4), 1317-1327. http:/ /dx.doi.org/10.1590/0001-3765201394612

Baptista Neto, J.A., Gingele, F.X., Leipe, T., Brehme, I., 2006. Spatial distribution of heavy metals in surficial sediments from Guanabara Bay: Rio de Janeiro, Brazil. Environmental Geology 49, 1051-1063. http://dx.doi.org/10.1007/s00254005-0149-1

Barth, O.M., Barreto, C.F., Coelho, L.G., Luz, C.F.P., 2004. Pollen record and paleoenvironment of 4210 years B.P. old sediment in the Bay of Guanabara, Rio de Janeiro, Brazil. Anais da Academia Brasileira de Ciências 76, 549-551. http:/ /dx.doi.org/10.1590/S0001-37652004000300009 
Bindler, R., 2011. Contaminated lead environments of man: Reviewing the lead isotopic evidence in sediments, peat, and soils for the temporal and spatial patterns of atmospheric lead pollution in Sweden. Environmental Geochemistry and Health 33(4), 311-329. https://doi.org/10.1007/s10653-011-9381-7

Bollhöfer, A.F., Rosman, K.J.R., Dick, A.L., Chisholm, W., Burton, G.R., Loss, R.D., Zahorowski, W., 2005. Concentration, isotopic composition, and sources of lead in Southern Ocean air during 1999/2000, measured at the Cape Grim Baseline Air Pollution Station, Tasmania. Geochimica et Cosmochimica Acta 69, 4747-4757. https://doi.org/10.1016/j.gca.2005.06.024

Bollhöfer, AW., Rosman, K.J.R., 2000 Sampling aerosols for lead isotopes on a global scale. Analytical Chimica 390, 227-235.

Borges, H.V., Nittrouer, C.A., 2016. Sediment accumulation in Sepetiba Bay (Brazil) during the Holocene: A reflex of the human influence. Journal of Sedimentary Environments 1(1), 90-106. htps://doi.org/10.12957/jse.2016.21868

Borges, A.C., Sanders, C.J., Santos, H.L.R., Araripe, D.R., Machado, W., Patchineelam, S.R., 2009. Eutrophication history of Guanabara Bay (SE Brazil) recorded by phosphorus flux to sediments from a degraded mangrove area. Baseline, Marine Pollution Bulletin 58 1750-1754. htps://doi.org/10.1016/j.marpolbul.2009.07.025

Bueno, C., Figueira, R., Ivanoff, M.D., Toldo Junior, E.E., Fornaro, L., García-Rodríguez, F.G., 2019. A multi proxy assessment of long-term anthropogenic impacts in Patos Lagoon, southern Brazil. Journal of Sedimentary Environments 4 (3), 276-290. htps://doi.org/10.12957/jse.2019.44612

Catanzaro, L.F., Baptista Neto, J.A., Guimarães, M.S.D., Silva, C.G., 2004. Distinctive sedimentary processes in Guanabara Bay - SE/Brazil, based on the analysis of echo-character (7.0 khz). Revista Brasileira de Geofísica 22 (1), 69-83.

Chow, T.J., Patterson, C.C., 1962. The occurrence and significance of lead isotopes in pelagic sediments. Geochimica et Cosmochimica Acta 26, 263-308.

Clarke, A.D., Shinozuka, Y., Kapustin, V.N., Howell, S., Huebert, B., Doherty, S., Anderson, T., Covert, D., Anderson, J., Hua, X., Moore, K.G., McNaughton, C., Carmichael, G., Weber, R., 2004. Size distributions and mixtures of dust and black carbon aerosol in Asian outflow: physiochemistry and optical properties. Journal of Geophysical Research Atmospheres 109, 15S09. https://doi.org/10.1029/2003JD004378

Cloy, J.M., Farmer, J.G., Graham, M.C., MacKenzie, A.B., Cook, G. T., 2008. Historical records of atmospheric Pb deposition in four Scottish ombrotrophic peat bogs: An isotopic comparison with other records from western Europe and Greenland. Global Biogeochemical Cycles, 22, Article Number: GB2016. htps://doi.org/ 10.1029/2007GB003059

Contador, L., Paranhos, R., 1996. Water quality trends in Urca inlet (Guanabara Bay, Brazil) between 1986 and 1992. Arquivos de Biologia Tecnologia 39, 735-744.

Delavy, F.P., Figueiredo Jr., A.G., Martins, M.V.A., Rodrigues, R., Pereira, E., Brito, M.A.R.C., Fonseca, M.C.M., Laut, L.L.M., Bergamaschi, S., Miranda, P., Rodrigues, M.A.C., 2016. High-resolution acoustic mapping of gas charged sediments and living benthic foraminifera assemblages from the NE region of the Guanabara Bay (RJ, Brazil).
Journal of Sedimentary Environments, 1 (3), 360-384. htps://doi.org/10.12957/jse.2016.26281

Desenfant, F., Veron, A.J., Camoin, G.F., Nyberg, J., 2006. Reconstruction of pollutant lead invasion into the tropical North Atlantic during the twentieth century. Coral Reefs, 25, 473-484. https://doi.org/10.1007/s00338-006-0113-x

Dias, P.P.B.B., Martins, M.V.A., Clemente, I.M.M.M., Carelli, T.G., Silva, F.S., Fontana, L.F., Lorini, M.L., Panigai, G., Pinheiro, R.H., Mendonça-Filho, J.G., Laut, L.L.M., 2017. Assessment of the Trophic State of Saquarema Lagoonal System, Rio de Janeiro (Brazil). Journal of Sedimentary Environments, 2 (1), 49-64. htps://doi.org/10.12957/jse.2017.28194

Díaz Morales, S.J., Guerra, J.V., Nunes, M.A.S, Alves Martins, M.V., Souza, A.M., Geraldes, M.C., 2019. Anthropogenic impacts on the western sector of Sepetiba Bay (SE do Brazil) accessed by the $\mathrm{Pb}$ isotope composition of surface sediments. Journal of Sedimentary Environments 4 (3), 291-311. htps://doi.org/10.12957/jse.2019.45269

Díaz Morales, S.J., Guerra, J.V., Nunes, M.A.S, Souza, A.M., Geraldes, M.C., 2019b. Evaluation of the environmental state of the western sector of Sepetiba Bay (SE Brazil): trace metal contamination. Journal of Sedimentary Environments, 4 (2), 174-188. htps://doi.org/10.12957/jse.2019.43764

Doucet, F.J., Carignan, J., 2001. Atmospheric isotopic composition and trace metal concentration as revealed by epiphytic lichens. Atmospheric Environment 35 (21), 36813690. https://doi.org/10.1016/S1352-2310(00)00510-0

Duzgoren-Aydin, N.S., Weiss A.L., 2008. Use and abuse of Pbisotope fingerprinting technique and GIS mapping data to assess lead in environmental studies. Environmental Geochemistry and Health 30 (6), 577-588 https://doi.org/10.1007/s10653-008-9179-4

Farmer, J. G., Eades, L. J., MacKenzie, A. B., Kirika, A., BaileyWatts, T. E., 1996. Stable lead isotope record of lead pollution in Loch Lomond sediments since 1630 A.D. Environmental Science and Technology 30, 3080-3083. https://doi.org/10.1021/es960162o

Farmer, J. G., Eades, L. J., Atkins, H., Chamberlin, D.F., 2002. Historical trends in the lead isotopic composition of archival Sphagnum mosses from Scotland (18382000). Environmental Science and Technology, 36, 152157. https://doi.org/10.1021/es010156e

Faure, G., 1986. Principles of isotope geology. $2^{\text {nd }}$ ed., New York: Wiley.

Ferrand, J.L., Hamelin, B., Monaco, A., 1999. Isotopic tracing of anthropogenic $\mathrm{Pb}$ inventories and sedimentary fluxes in the Gulf of Lions (NW Mediterranean Sea). Continental Shelf Research 19 (1), 23-47. https://doi.org/10.1016/S02784343(98)00070-3

Geraldes, M.C., Paula, A.H., Godoy, J.M., Valeriano, C.M., 2006. $\mathrm{Pb}$ isotope signatures of sediments from Guanabara Bay, SE Brazil: evidence for multiple anthropogenic sources. Journal of Geochemical Exploration 88 (1-3), 384-387.

Gioia, S.M.C.L., Pimentela, M.M, Tessler, M., Dantas, E.L., Campos, J.E.G., Guimarães, E.M., Maruoka, M.T.S., Nascimento, E.L.C. 2006. Sources of anthropogenic lead in sediments from an artificial lake in Brasilia-central Brazil. Science of The Total Environment 356 (1-3), 125-142. https://doi.org/10.1016/j.scitotenv.2005.02.041 
Godoy, J.M, Moreira, I., Bragança, M.J., Wanderley, C., Mendes, LB., 1998. A study of Guanabara Bay sedimentation rates. Journal of Radioanalytical and Nuclear Chemistry 227 (1-2), 157-160. https://doi.org/10.1007/BF02386450

Graham, M.C., Vinogradoff, S.I., Chipchase, A.J., Dunn, S.M., Bacon, J.R., Farmer, J.G., 2006. Using size fractionation and $\mathrm{Pb}$ isotopes to study $\mathrm{Pb}$ transport in the waters of an organic-rich upland catchment. Environmental Science and Technology 40, 1250-1256. https://doi.org/10.1021/es0517670

Gulson, B.L., Church, S.E., Mizon, K.J., Meier, A.L., 1992. Lead isotopes in iron and manganese oxide coatings and their use as an exploration guide for concealed mineralization. Applied Geochemistry 7, 495-511. https://doi.org/10.1016/08832927(92)90067-D

Ignacio, M., Robert, I., Tavares, A.D., Pessoa, I., Alves Martins, M.V., Almeida, B.S., Geraldes, M.S., 2019. Evaluation by LAMC-ICP-MS of NIST $612 \mathrm{~Pb}$ isotopic composition as external reference material and a robust proxy for environmental characterization using (carbonatic) bivalves shells. International Journal of Mass Spectrometry 446, 116196. https://doi.org/10.1016/j.ijms.2019.116196

INEA, Instituto do Ambiente, Estado do Rio de Janeiro. http://www.inea.rj.gov.br/Portal/MegaDropDown/Monitor amento/Qualidadedaagua/Baias/BaiadaGuanabara/index.ht m. Accessed on 22/09/2019

Kaste, J. M., Friedland, A. J., Sturup, S., 2003. Using stable and radioactive isotopes to trace atmospherically deposited $\mathrm{Pb}$ in montane forest soils. Environmental Science and Technology 37, 3560-3567. https://doi.org/10.1021/es026372k

Kjerfve, B., Ribeiro, C.H., Dias G.T., Filippo, A.M., Quaresma, V.S., 1997. Oceanographic characteristics of an impacted coastal bay: Baía de Guanabara, Rio de Janeiro, Brazil Continental Shelf Research 17, 1609-1643. https://doi.org/10.1016/S0278-4343(97)00028-9

Kober, B., Wessels, M., Bollhofer, A., Mangini, A., 1999. Pb isotopes in sediments of Lake Constance, Central Europe constrain the heavy metal pathways and the pollution history of the catchment, the lake and the regional atmosphere. Geochimica et Cosmochimica Acta 63, 1293-1303. 10.1016/S0016-7037(99)00064-2

Komárek, M., Ettler, V., Chrastný, V., Mihaljevič, M., 2008. Lead isotopes in environmental sciences: A review. Environment International 34, 562-577. https://doi.org/10.1016/j.envint.2007.10.005

Laut, L., Alves Martins, M.V., Belart, P., Lorini, M.L., Clemente, I., Nogueira, L., Juliace, A., Fontana, L.F., 2019. Organic compounds as proxies of the sedimentary environmental quality of the Maricá-Guarapina Lagoon System (SE, Brazil). Journal of Sedimentary Environments 4 (2), 159-173. https://doi.org/10.12957/jse.2019.43371

Laut, L.L.M., Martins, M.V.A., Fontana, L.F., Silva, F.S., Mendonça-Filho, J.G., Clemente, I.M.M.M., Frontalini, F., Raposo, D., Belart, P., Ballalai, J., 2016. Ecological status evaluation of Itaipu Lagoon (Niterói) based on biochemical composition of organic matter. Journal of Sedimentary Environments 1(3), htps://doi.org/10.12957/jse.2016.25903

Le Roux, G., Aubert, D., Stille, P., Krachler, M., Kober, B., Cheburkin, A., Bonani, G., Shotyk, W., 2005. Recent
RESEARCH PAPER

atmospheric $\mathrm{pb}$ deposition at a rural site in southern Germany assessed using a peat core and snowpack, and comparison with other archives. Atmospheric Environment, 39, 6790-6801. https://doi.org/10.1016/j.atmosenv.2005.07.026

Leybourne, M.I., Cousens, B.L., Goodfellow, W.D., 2009. Lead isotopes in ground and surface waters: Fingerprinting heavy metal sources in mineral exploration. Geochemistry Exploration Environment Analysis 9(2), 115-123. https://doi.org/10.1144/1467-7873/09-195

Machado, W., Carvalho, M.F., Santelli, R.E., Maddock, J.E.L., 2004. Reactive sulfides relationship with metals in sediments from an eutrophicated estuary in Southeast Brazil. Marine Pollution Bulletin 49, 89-92. https://doi.org/10.1016/j.marpolbul.2004.01.012

Martins, M.V.A., Laut, L., Duleba, W., Zaaboub, N., Aleya, L., Terroso, D.L., Sequeira, C., Pena, A., Rodrigues, M.A., Rocha, F., 2017. Sediment quality and possible uses of dredged materials: the Ria de Aveiro lagoon mouth area (Portugal). Journal of Sedimentary Environments 2 (2), 149-166. https://doi.org/10.12957/jse.2017.30055

Martins, M.V.A., Laut, L.L.M., Frontalini, F., Sequeira, C., Rodrigues, R., Fonseca, M.C.F., Bergamaschi, S., Pereira, E., Delavy, F.P., Figueiredo Jr., A.G., Miranda, P., Terroso, D., Pena, A.L., Laut, V.M., Figueira, R., Rocha, F., $2016 a$. Controlling factors on the abundance, diversity and size of living benthic foraminifera in the NE sector of Guanabara Bay (Brazil). Journal of Sedimentary Environments 1(4), 393-410. htps://doi.org/10.12957/jse.2016.26872

Martins, M.V.A., Soares-Gomes, A., Yamashita, C., Pinto, A.F.S., Frontalini, F., Sequeira, C., Laut, L.L.M., Belart, P., Zaaboub, N., Miranda, P., Sousa, S.H.M., Figueira, F., Pena, A.L., Terroso, D.L., Fernando Rocha, F., 2016 b. Similarity between the dead and living foraminiferal assemblages of the NE sector of Guanabara Bay (Brazil). Journal of Sedimentary Environments 1(4), 411-431. htps://doi.org/10.12957/jse.2016.26875

Martins, V.A., Silva, F., Lazaro, L.M.L., Frontalini, F., Clemente, I.M., Miranda, P., Figueira, R., Sousa, S.H.M., Dias, J.M.A., 2015. Response of benthic foraminifera to organic matter quantity and quality and bioavailable concentrations of metals in Aveiro Lagoon (Portugal). PLoS ONE 10 (2), e0118077. https://doi.org/10.1371/journal.pone.0118077

Mayr, L.M., Tenenbaum, D.R., Villac, M.C., Paranhos, R., Nogueira, C.R., Bonecker, S. L.C., Bonecker, A.C.T., 1989. Hydrological characterization of Guanabara Bay. In: Maggon, O., Neves, C. (eds), Coastlines of Brazil, New York, NY: American Society of Civil Engineers, 124-138.

Miller, J.R., Anderson, J.B., Lechler, P.J., Kondrad, S.L., Galbreath, P.F. \& Salter, E.B., 2005. Influence of temporal variations in water chemistry on the $\mathrm{Pb}$ isotopic composition of rainbow trout (Oncorhynchus mykiss). Science of The Total Environment 350, 204-224. htps://doi.org/10.1016/j.scitotenv.2005.01.030

Miller, J.R., Lechler, P.J., Hudson-Edwards, K.A., Macklin, M.G., 2002. Lead isotopic fingerprinting of heavy metal contamination, Rio Pilcomayo basin, Bolivia. Geochemistry: Exploration, Environment, Analysis 2, 225-233. https://doi.org/10.1144/1467-787302-026

Misailidis, M.L., Machado, W., Perez Segovia, A.P., Strikis, N.M., Strikis, P.C., Pregnolato, L.A., Duleba, W., 2018. 
Anthropogenic factors driven phosphorus contents in Salto Grande Reservoir sediments, São Paulo State (SE Brazil). Journal of Sedimentary Environments 3 (3), 166-175. https://doi.org/10.12957/jse.2018.37958

Moraes, R.P., Figueiredo, B.R., Lafon, J.M., 2004. Pb-isotopic tracing of metal-pollution sources in the Ribeira Valley, southeastern Brazil. Terrae 1(1), 19-26.

Moura, C.A.V., Gaudette, H.E., Carvalho, M.C., Morales, G.P., 2004. The use of lead isotope composition as a tool to investigate the anthropogenic impacts on the environment in the metropolitan region of Belém (Pará State, Brazil). Terræ 1 (1), 9-18. http://www.ige.unicamp.br/terrae/scientific/vol1_n $1 /$ mouraa.htm.

Nriagu, J.O., 1990. The rise and fall of leaded gasoline. The Science of the Total Environment 92, 1-28. https://doi.org/10.1080/15275920903346794

Oh, Y.K., Ryu, S.P., Kim, H.C., Kawamura, H., Tennichi, Y., Matsuoka, N., Maeda, Y., 2004. Source identification of $\mathrm{Pb}$ in aerosols at Jeju-do, Korea by using $207 \mathrm{~Pb} / 206 \mathrm{~Pb}$ and $208 \mathrm{~Pb} / 206 \mathrm{~Pb}$. Journal of Radioanalytical and Nuclear Chemistry 260 (2), 279282. https://doi.org/10.1023/B:JRNC.0000027096.30062.74

Pace, M.L., Lovett, G.M. 2013. Chapter 2 - Primary Production: The Foundation of Ecosystems. In Weathers, K.C., Stayer, D.L., Likens, G.E., Fundamentals of Ecosystem Science, Academic Press, pp. 27-51. https://doi.org/10.1016/B978-008-091680-4.00002-0

Paranhos, R., Nascimento, S.M., Mayr, L.M., 1995. On the faecal pollution in Guanabara Bay, Brazil. Fresenius Environmental Bulletin 4, 352-357.

Patchineelam, S.R., Smoak, J.M., 1999. Sediment accumulation rates along the inner eastern Brazilian continental shelf. Geo-Marine Letters 19, 196-201. https://doi.org/10.1007/s003670050109

Patterson, C.C., Hirao, Y., 1974. Lead aerosol pollution in the high sierras overrides natural mechanisms which exclude lead from a food chain. Science 184, 989-992.

Patterson, C., 1965. Contaminated and natural environments of man. Archives of Environmental Health, 11, 344-360.

Peixoto, T.C.S, 2005. Geocronologia e fluxos de carbono orgânico em sedimentos recentes da porção norte da Baía de Guanabara, RJ. Undergraduate Monograph. Departamento de Oceanografia, Universidade do Estado do Rio de Janeiro UERJ, Rio de Janeiro, 52 p.

Pennafirme, S., Lima, I., Bitencourt, J., Crapez, M., Lopes, R., 2015. Organic Matter Biodegradation by Bacterial Consortium under Metal Stress. In: Chamy, R., Rosenkranz, F. (eds), Chapter 4, Biodegradation and Bioremediation of Polluted Systems - New Advances and Technologies, IntechOpen, pp. 67-84. http://dx.doi.org/10.5772/60980

Pereira, E., Baptista Neto, J.A., Smith, B.J., Mcallister, J.J., 2007. The contribution of heavy metal pollution derived from highway runoff to Guanabara Bay sediments - Rio de Janeiro /Brazil. Anais da Academia Brasileira de Ciências 79 (4), 739-750. http://dx.doi.org/10.1590/S0001-37652007000400013

Potratz, G.l., Geraldes, M.G.G., Bizzi, S., Nogueira, L., Alves Martins, M.V., 2019. Using lead isotopes and potentially toxic elements to trace pollutant sources in the northern region of
RESEARCH PAPER

Guanabara Bay, southeastern Brazil. Marine Pollution Bulletin 144, 216-223 https://doi.org/10.1016/j.marpolbul.2019.04.057

Pregnolato, L.A., Viana, R.A., Passos, C.C., Misailidis, M.L., Duleba, W., 2018. Ammonia-Elphidium index as a proxy for marine pollution assessment, Northeast Brazil. Journal of Sedimentary Environments 3 (3), 176-186. https://doi.org/10.12957/jse.2018.38001

Rosman, K.J.R., Chisholm, W., Boutron, C.F., Candelone, J.P., Hong, S., 1994. Isotopic evidence to account for changes in the concentration of lead in Greenland snow between 1960 and 1988. Geochimica et Cosmochimica Acta 58, 3265-3269. https://doi.org/10.1016/0016-7037(94)90054-X

Saliba, B.S.A., Geraldes, M.C., Fernandes, R.R.D., 2011. O Impacto Ambiental da Contaminação de Metais Pesados na Baía de Guanabara: Aplicação de Isótopos de $\mathrm{Pb}$ em Sedimentos Quaternários para Identificação de Fontes Antropogênicas e Naturais. XIII Congresso da Associação Brasileira de Estudos do Quaternário ABEQUA/III Encontro do Quaternário Sulamericano/XIII ABEQUA Congress - The South American Quaternary: Challenges and Perspectives. http://www.abequa.org.br/trabalhos/Saliba $\% 20 B \% 20$ S $\% 20$ A $\% 20$ et $\% 20$ al.pdf

SEMADS, 2001. Bacias Hidrográficas e Rios Fluminenses, Síntese Informativa por Macrorregião Ambiental- Projeto Planágua SEMADS/GTZ, Secretaria de Estado de Meio Ambiente e Desenvolvimento Sustentável do Rio de Janeiro, Rio de Janeiro, RJ.

Shirahata, H., Elias, R.W., Patterson, C.C., 1980. Chronological variations in concentrations and isotopic compositions of anthropogenic atmospheric lead in sediments of a remote subalpine pond. Geochimica et Cosmochimica Acta, 44, 149_ 162. https://doi.org/10.1016/0016-7037(80)90127-1

Shotyk, W., Weiss, D., Appleby, P. G., Cheburkin, A. K., Frei, R., Gloor, M., Kramers, J. D., Reese, S., Van Der Knaap, W. O., 1998. History of atmospheric lead deposition since $12,370{ }^{14} \mathrm{C}$ yr BP from a peat bog, Jura Mountains, Switzerland. Science, 281, 1635-1640.

Simoneit, B R.T., Kobayashi, M., Mochida, M., Kawamura, K., Lee, M., Lim, H.J., Turpin, B. J., Komazaki, Y., 2004. Composition and major sources of organic compounds of aerosol particulate matter sampled during the ACE-Asia campaign. Journal of Geophysical Research: Atmospheres 109, 19S10. https://doi.org/10.1029/2004JD004598

Souza, A.M., Geraldes, M.C., Santos, A.C., 2017. Assessment of anthropic sources through PB isotopes in São Domingos Basin, Rio de Janeiro, Brazil. Journal of Sedimentary Environments 2 (2), 99-110. htps://doi.org/10.12957/jse.2017.29896

Steinnes, E., Sjøbakk, T.E., Donisa, C., Brännvall, M.L., 2005. Quantification of pollutant lead in forest soils. Soil Science Society of America Journal 69 (5), 1399-1404.

Suzuki, K.N., Sondermann, N.N., Machado, E.C., Machado, W., Bellido, A.V.B., Bellido, L.F., Lopes, R.T., 2016. Metal sorption by sediments from a mangrove reforestation area in Guanabara Bay (SE Brazil) revealed by using radiotracers. Journal of Sedimentary Environments 1(3), 292-296. htps://doi.org/10.12957/jse.2016.23707

Tserenpil, Sh., Sapkota, A., Liu, C.-Q., Peng, J.-H., Liuc, B., Segebade, P. Chr. 2016. Lead Isotope and Trace Element 
Composition of Urban Soils in Mongolia. Eurasian Soil Science 49 (8), 879-889.

Turekian, K., Holland, H. (Editors), 2013. Treatise on Geochemistry. 2nd Edition, Elsevier Science, pp. 9144.

Vilela, C.G., Figueira, B., Macedo, M.C., Baptista Neto, J.A., 2014. Late Holocene evolution and increasing pollution in Guanabara Bay, Rio de Janeiro, SE Brazil. Marine Pollution Bulletin 79 (1-2), 175-187. http://dx.doi.org/10.1016/j.marpolbul.2013.12.020

Watmough, S.A., Hutchinson, T.C., Dillon, P.J., 2004. Lead dynamics in the forest floor and mineral soil in south-central Ontario. Biogeochemistry 71, 43-68. https://doi.org/10.1007/s10533-005-

Weiss, D., Shotyk, W., Kramers, J.D., Gloor, M., 1999. Sphagnum mosses as archives of recent and past atmospheric lead
RESEARCH PAPER

deposition in Switzerland. Atmospheric Environment 33, 3751-3763. https://doi.org/10.1016/S1352-2310(99)00093-X

Widory, D., Liu, X., Dong, S., 2010. Isotopes as tracers of sources of lead and strontium in aerosols (TSP PM2.5) in Beijing. (TSP PM2.5) in Beijing. Atmospheric environment 44 (30), 36793687. https://doi.org/10.1016/j.atmosenv.2010.06.036

Zaaboub, N., Martins, M.V.A., Terroso, D., Helali, M.A., Béjaoui, B., El Bour, M., Boukef-BenOmrane, I., Pereira, A.L., Dardon, U., Oueslati, W., Ennouri, R., Galgani, F., Ferreira da Silva, E., Rocha, F., Aleya, L., 2016. Geochemical and mineralogical fingerprints of the sediments supply and early diagenetic processes in the Bizerte Lagoon (Tunisia). Journal of Sedimentary Environments 1(4), 440-456. https://doi.org/10.12957/jse.2016.26881 